\title{
Comprehensive Overview of Toxoplasma gondii-Induced and Associated Diseases
}

\author{
Darine Daher 1,+D, Ahmad Shaghlil ${ }^{2,+}$, Eyad Sobh ${ }^{2,+}$, Maguy Hamie ${ }^{1}$, Malika Elhage Hassan ${ }^{1}$ (D), \\ Mohamad Bahij Moumneh ${ }^{1}$, Shaymaa Itani ${ }^{1}$, Rana El Hajj ${ }^{3}$, Lina Tawk ${ }^{4}$, Marwan El Sabban ${ }^{5}$ and Hiba El Hajj ${ }^{1, *}$
}

check for

updates

Citation: Daher, D.; Shaghlil, A.; Sobh, E.; Hamie, M.; Hassan, M.E.; Moumneh, M.B.; Itani, S.; El Hajj, R.; Tawk, L.; El Sabban, M.; et al. Comprehensive Overview of Toxoplasma gondii-Induced and Associated Diseases. Pathogens 2021, 10, 1351. https://doi.org/10.3390/ pathogens10111351

Academic Editor: Geoff Hide

Received: 14 September 2021

Accepted: 14 October 2021

Published: 20 October 2021

Publisher's Note: MDPI stays neutral with regard to jurisdictional claims in published maps and institutional affiliations.

Copyright: (c) 2021 by the authors. Licensee MDPI, Basel, Switzerland. This article is an open access article distributed under the terms and conditions of the Creative Commons Attribution (CC BY) license (https:/ / creativecommons.org/licenses/by/ $4.0 /)$.
1 Department of Experimental Pathology, Microbiology and Immunology, Faculty of Medicine, American University of Beirut, Beirut 1107 2020, Lebanon; dkd04@mail.aub.edu (D.D.); mh242@aub.edu.lb (M.H.); mae87@mail.aub.edu (M.E.H.); mmm106@mail.aub.edu (M.B.M.); ski02@mail.aub.edu (S.I.)

2 Department of Biology, Faculty of Sciences, R. Hariri Campus, Lebanese University, Beirut 1107 2020, Lebanon; ahmad.shaghlil.98@gmail.com (A.S.); eyadsobh18@gmail.com (E.S.)

3 Department of Biological Sciences, Beirut Arab University, Beirut 1107 2809, Lebanon; r.hajj@bau.edu.lb

4 Department of Medical Laboratory Sciences, Faculty of Health Sciences, University of Balamand, Beirut 1100 2807, Lebanon; lina.tawk@balamand.edu.lb

5 Department of Anatomy, Cell Biology and Physiological Sciences, Faculty of Medicine, American University of Beirut, Beirut 1107 2020, Lebanon; me00@aub.edu.lb

* Correspondence: he21@aub.edu.lb; Tel.: +961-1-350000 (ext. 4897)

+ These authors contributed equally to this work.

Abstract: Toxoplasma gondii (T. gondii) is a prevalent protozoan parasite of medical and veterinary significance. It is the etiologic agent of toxoplasmosis, a neglected disease in which incidence and symptoms differ between patients and regions. In immunocompetent patients, toxoplasmosis manifests as acute and chronic forms. Acute toxoplasmosis presents as mild or asymptomatic disease that evolves, under the host immune response, into a persistent chronic disease in healthy individuals. Chronic toxoplasmosis establishes as latent tissue cysts in the brain and skeletal muscles. In immunocompromised patients, chronic toxoplasmosis may reactivate, leading to a potentially life-threatening condition. Recently, the association between toxoplasmosis and various diseases has been shown. These span primary neuropathies, behavioral and psychiatric disorders, and different types of cancer. Currently, a direct pre-clinical or clinical molecular connotation between toxoplasmosis and most of its associated diseases remains poorly understood. In this review, we provide a comprehensive overview on Toxoplasma-induced and associated diseases with a focus on available knowledge of the molecular players dictating these associations. We will also abridge the existing therapeutic options of toxoplasmosis and highlight the current gaps to explore the implications of toxoplasmosis on its associated diseases to advance treatment modalities.

Keywords: toxoplasmosis; neuropathies; psychiatric disorders; behavioral disorders; neurological disorders

\section{Introduction}

Toxoplasma gondii (T. gondii) is an obligate intracellular parasite that infects a broad range of animals including approximately one third of the world's human population [1] The prevalence of T. gondii infection varies widely between countries [2]. In North America, South East Asia, and Northern Europe, prevalence is low and ranges between 10 and 30\%. In Central and Southern Europe, a moderate prevalence is reported and ranges between 30 and 50\%, while in Latin America and tropical African countries, a high prevalence is common and reaches an alarming percentage of $80 \%$ in certain regions [2]. The Center for Disease Control and Prevention (CDC) reported that more than 40 million people in the United States are infected with this parasite, and classified toxoplasmosis among the neglected parasitic infections requiring public health action control [3]. 
The T. gondii life cycle involves a sexual stage occurring in the intestinal epithelium of felines and an asexual part involving any warm-blooded animal. It exhibits three morphologically distinct infectious stages: tachyzoites (responsible for acute toxoplasmosis leading to tissue damage), bradyzoites (responsible for chronic toxoplasmosis manifested as cysts in the brain and skeletal muscle tissues), and sporozoites (infective forms found in oocysts shed in cats' feces). Human infection starts following the oral ingestion of sporulated oocysts in food or water contaminated with felines' feces, or upon the ingestion of tissue cysts after the consumption of contaminated raw or undercooked meat. Vertical transmission follows the transplacental spread of tachyzoites from a primo-infected pregnant mother to her fetus/baby, leading to congenital toxoplasmosis.

\section{Toxoplasma gondii Pathogenesis}

The manifestations of toxoplasmosis differ between patients (Figure 1). In the sections below, we will provide an overview on the direct pathogenesis of T. gondii spanning acute, chronic, congenital, and ocular infection and reactivated chronic toxoplasmosis. We will also summarize the reported literature on T. gondii-associated diseases.

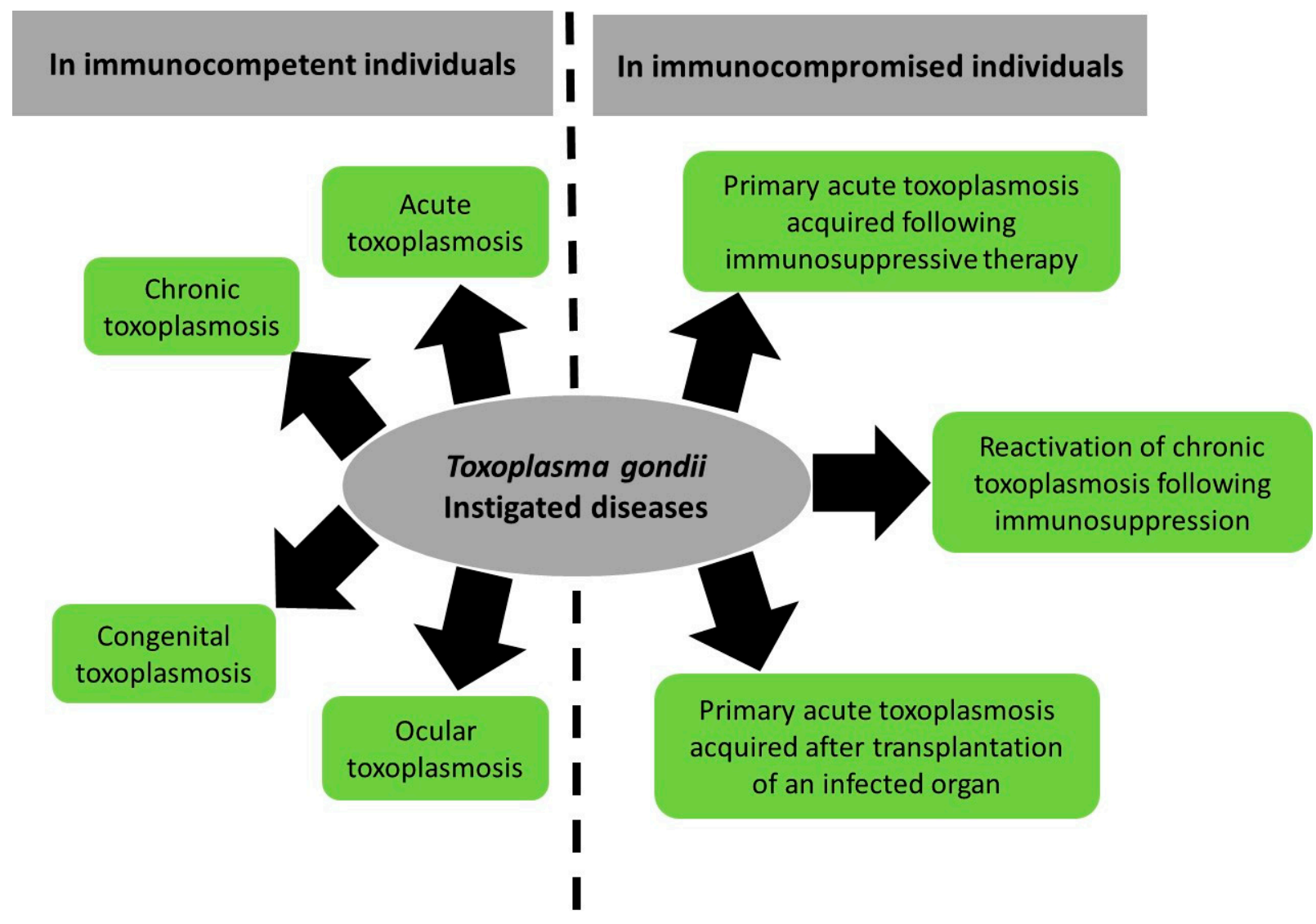

Figure 1. Summary of Toxoplasma gondii-induced diseases and their spectrum between immunocompetent and immunocompromised patients.

\subsection{Toxoplasmosis in Immunocompetent Patients \\ 2.1.1. Acute Toxoplasmosis}

Acute toxoplasmosis develops after an incubation period of a few days following tachyzoites' spread and replication. It is asymptomatic in more than $80 \%$ of immunocompetent individuals $[4,5]$. It can manifest with flu-like symptoms including fever and mononucleosis-like symptoms, with cervical posterior adenopathy, myalgia, and asthenia [4]. Occasionally, chorioretinitis may occur. The severity of infection is also related to the genotype of the parasite strain. In North America and Europe, six genetic markers were 
used to group T. gondii strains into clonal lineage I, II, and III, with I considered to have the highest virulence in preclinical mouse models, II less virulence, and III considered to be avirulent [6]. In French Guiana and Latin America, atypical strains showed high genetic diversity and represented a severe acquired toxoplasmosis among immunocompetent individuals. These subjects developed fatal pneumonitis, myocarditis, meningo-encephalitis, and polymyositis [2]. Tachyzoites disseminate to the brain and the skeletal muscles, and after the onset of the host immune system, they convert into bradyzoite cysts, initiating the chronic form of the disease. To enter the CNS, three mechanisms have been proposed: the "Trojan horse" mechanism, through which the parasite highjacks an immune cell to enter, the paracellular crossing mechanism, and the transcellular crossing mechanism [7]. The "Trojan horse" mechanism was based on several in vitro studies showing that infected immune cells exhibit increased motility and are capable of crossing endothelial barriers [8-10]. Furthermore, intravenous inoculation of mice with infected macrophages or dendritic cells resulted in the hastened appearance of the parasites in the CNS when compared to the inoculation of mice with free tachyzoites $[9,11]$. In the paracellular mechanism of entry, it has been proposed that T. gondii uses its actin-myosin motors, hence gliding motility, to cross the BBB [12].

\subsubsection{Congenital Toxoplasmosis}

In sero-negative pregnant women, primary infection with T. gondii occurs following the placental transmission of the parasite to the fetus [13]. The degree of severity of congenital toxoplasmosis is inversely related to the gestational trimester at which the infection is acquired [14]. Although the placenta represents a major forefront that inhibits tachyzoites' transmission in the beginning of gestation, this ability decreases gradually throughout the pregnancy, allowing the tachyzoites to move between cells and infect the fetus [15]. It is estimated that about $25 \%$ of $T$. gondii transmission takes place in the first trimester, whereas $54 \%$ and $65 \%$ of transmission occur in the second and third trimesters, respectively [16]. Infection of the fetus during the first trimester often leads to abortion, stillbirth, or a child born with severe abnormalities of the brain and eyes, such as hydrocephalus, intracranial calcifications, deafness, mental retardation, seizures, retinochoroiditis, and even blindness (reviewed in [17]). Transmission to the fetus in the second or third trimester is less likely to cause such severe clinical manifestations, but may result in subclinical disease, which may lead to retinochoroiditis or learning difficulties after birth [18]. It is worth noting that the percentage of acquiring toxoplasmosis during pregnancy varies according to regions and prevalence $[19,20]$, and re-infection with atypical T. gondii genotypes was reported even in sero-positive pregnant women [21], and resulted in a more severe congenital toxoplasmosis [22].

\subsubsection{Ocular Toxoplasmosis}

T. gondii is one of the primary causes of infectious uveitis worldwide, typically presenting with retinochoroiditis [23]. Ocular toxoplasmosis mostly occurs after an acquired congenital toxoplasmosis. Yet, some studies reveal postnatal acquired infections leading to this manifestation [24]. Clinical features of ocular toxoplasmosis depend on the anatomical location of the lesion [25]. Typically, retinochoroiditis is the most predominant indication of active intraocular inflammation. It presents with posterior uveitis, vitritis, focal necrotizing granulomatous retinitis, and reactive granulomatous choroiditis [26]. The rupture of intra-retinal cysts may lead to the reactivation of ocular toxoplasmosis, triggering a rapid localized immune reaction involving mostly Interleukin-17A [27].

\subsubsection{Chronic Toxoplasmosis}

T. gondii can be classified as a primarily neurotropic pathogen, having a higher affinity for the central nervous system over other organs (reviewed in [28]). To reach the brain parenchyma from the cerebral blood circulation, different strains of T. gondii cross the brain endothelium to the capillary bedding through either hijacking leukocytes or as free 
parasites [7]. Once the blood brain barrier is crossed, the host immune response, among other factors including intracellular neuronal homeostasis, is triggered, and consequently, T. gondii tachyzoites switch to forming bradyzoite cysts, which are the hallmark of the chronic phase of the infection. These intraneuronal cysts are controlled but not eliminated by the immune system (reviewed in [29,30]). Although bradyzoites are slowly replicating forms, their replication affects the structure of the neurons and disrupt their connection. Furthermore, these tissue cysts trigger a brain-specific immune response (reviewed in [30]). Brain-resident cells including astrocytes, microglia, and neurons contribute to the intracerebral immune response by the production of cytokines, chemokines, and the expression of immune-regulatory cell surface molecules, such as major histocompatibility (MHC) antigens (reviewed in $[29,30]$ ). Circulating immune cells are also recruited to the site of infection in the CNS and contribute to the response against the infection [31,32]. The release of different cytokines, such as interleukins and interferons, including IL12, IL$1 \beta$, IL-6, and iNOS, among others, in addition to tumor necrosis factor-alpha (TNF- $\alpha$ ) and interferon-gamma (IFN- $\gamma$ ), which activates IFN-inducible GTPases, is important for the cell-autonomous immunity and is effective to inhibit T. gondii replication ([33-37], reviewed in [31]). Infiltrating $\mathrm{CD}^{+}$and $\mathrm{CD} 8^{+} \mathrm{T}$ cells release several cytokines, mainly IFN- $\gamma$ (reviewed in [30]). The immune response causes brain inflammation, which leads to ventricular dilatation, disrupting neuronal structure and connectivity [38-40]. Morphological changes include altered fiber density, loss of fiber continuity, a reduction in postsynaptic density protein 95 (PSD95) and synaptophysin, and synaptic proteins. The reduction in dendritic spines leads to a decrease in network activity [41,42]. Hence, a balance between the host immune response and the parasitic modulators controls the persistence and progression of toxoplasmosis. Direct symptoms of chronic toxoplasmosis are not fully unraveled, and most published studies correlate this disease status with neuropathies with only little molecular proof $[43,44]$ (see sections below). Yet, the reactivation of chronic toxoplasmosis following immunosuppression is frequently reported and may lead to dire consequences reaching death.

\subsection{Toxoplasmosis in Immunocompromised Patients}

The host immune response plays a key role in the control of parasite replication and maintenance of tissue cysts. With the growing number of individuals receiving immune-suppressive therapies, clinicians are aware of the potential occurrence of Toxoplasma encephalitis, not only during the reactivation of latent infection, but also as a primary infection [45]. Indeed, despite the availability of prophylactic and treatment options, the reactivation of chronic toxoplasmosis still occurs and can become life threatening [4,46-48]. In immunocompromised patients, the reactivation of chronic toxoplasmosis is due to various factors impairing the protective cellular immune response such as HIV infection, immunosuppressive therapies administered in the context of hematopoietic stem cell transplantation, solid organ transplant, or chemotherapy against cancer [30,49-54]. In HIV patients, toxoplasmic encephalitis is the predominant manifestation of the disease, while pulmonary or disseminated toxoplasmosis is more characteristic of transplant patients $[2,55]$. These patients present with neurologic symptoms, most frequently diffuse encephalopathy, meningoencephalitis, cerebral mass lesions, headaches, confusion, poor coordination, and seizures. Moreover, in patients with HIV, an association between CD4 counts and the prevalence of $T$. gondii-related neurologic symptoms was reported [47]. In that sense, the reactivation of chronic toxoplasmosis becomes a concern when the CD4 count falls below 200 cells/microliter [47]. This reactivation is due to the consequential decrease in IFN- $\gamma$ and cytokine production, leading to impaired cytotoxic T-lymphocyte activity. Recent data revealed that HIV patients who presented with symptoms of fever and dizziness as part of their Toxoplasma encephalitis prodrome sought medical care quicker than those who did not present with these symptoms, leading to the swift administration of treatment, thus reducing mortality [56]. 
The reactivation of chronic toxoplasmosis was also reported following chemotherapy administration. Indeed, several cases of reactivation of cerebral toxoplasmosis following rituximab therapy were described [57-60]. The reactivation of toxoplasmosis is also a concern in solid organ transplant recipients, either as a manifestation derived from an infected donor, a reactivation of chronic toxoplasmosis in the recipient, or to a much lesser extent, a primary acquired infection following transplantation. The highest risk of toxoplasmosis was described in orthotopic heart transplant recipients due to the propensity of bradyzoite cysts to form in striated muscles. This enhanced the screening for T. gondii in these patients prior to transplantation [61]. A retrospective review of solid organ transplant and hematopoietic stem cell transplant recipients with toxoplasmosis between 2002 and 2018 at two large US academic transplant centers was recently conducted. The median time from transplant to toxoplasmosis diagnosis was longer for solid organ transplants than for hematopoietic stem cell transplants, and clinical manifestations were encephalitis (65\%), respiratory failure $(40 \%)$, renal failure $(40 \%)$, and distributive shock $(40 \%)$. The cohort 30 -day mortality was $45 \%$, and the 90 -day mortality was $55 \%$ of the cohort [62].

\section{Toxoplasma gondii-Associated Diseases}

In healthy individuals, chronic toxoplasmosis was regarded as clinically asymptomatic [63]. However, an increasing number of associations are being made between various medical conditions and T. gondii infections [63]. These comprise primary neuropathies, behavioral and psychiatric disorders, and different types of cancer [64].

\subsection{Toxoplasma gondii and Primary Neuropathies}

Associations between T. gondii infection and primary neurologic diseases such as multiple sclerosis, epilepsy, and Parkinson's and Alzheimer's disease remain limited to correlation, controversial studies, and lack a direct molecular proof (Figure 2). In this review, a brief overview of the known literature will be covered.

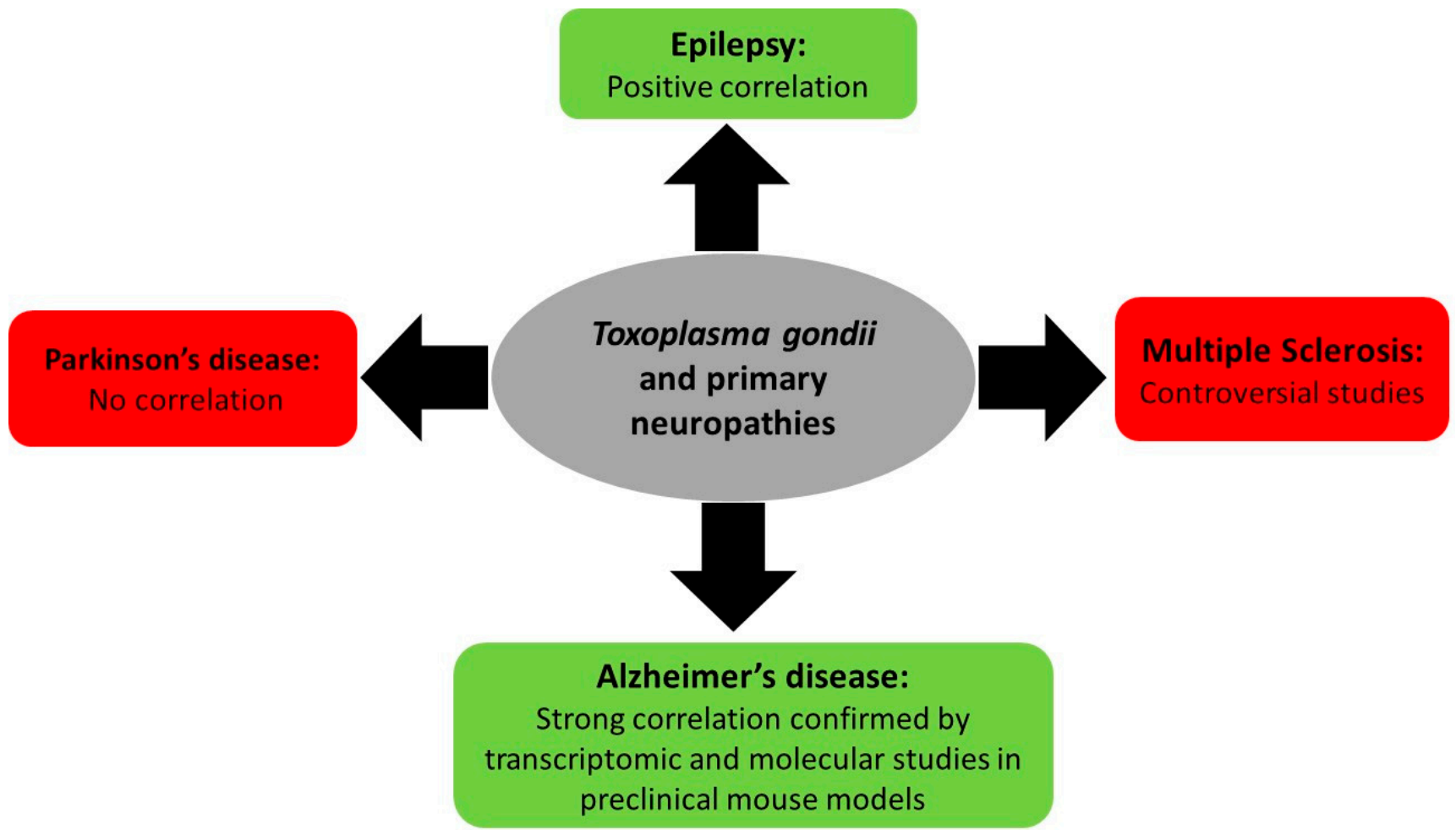

Figure 2. Summary of Toxoplasma gondii-associated primary neuropathy diseases and their outcome. 


\subsubsection{Toxoplasmosis and Multiple Sclerosis}

Multiple sclerosis (MS) is a chronic autoimmune inflammatory multifactorial disease that affects the nervous system, leading to cognitive, neurological, and physical disabilities. Associations between T. gondii and MS relied on data collected from five studies (up to April 2017, 669 MS patients and 770 controls). Four out of five studies showed a negative association between $T$. gondii and MS and only one unveiled a positive association [65]. Another study, which included 164 patients and 481 controls, revealed a negative association between both diseases [66]. More recently, a systematic review including all published articles up to November 2020, which used a random effects model for a global population of $752 \mathrm{MS}$ cases and 1282 controls, added to the controversies. It reported a pooled odds ratio of $0.68(95 \%$ confidence interval $=0.50-0.93)$, suggesting that toxoplasmosis may play a protective role against MS [67].

\subsubsection{Toxoplasmosis and Epilepsy}

A systematic literature review used the random effects model on all published articles correlating toxoplasmosis and epilepsy, and showed a calculated odds ratio of 2.25, favoring the association between these two diseases and revealing toxoplasmosis as an epilepsy risk factor [68]. Cryptogenic epilepsies represent $20 \%$ of epilepsy syndromes with an unknown etiology that are usually due to a suspected underlying brain disease [69]. A study investigated the correlation between cryptogenic epilepsy and toxoplasmosis by choosing a subpopulation of cryptogenic epilepsy patients and testing for T. gondii antibodies. The results were compared with known-cause epilepsy patients and with controls. Cryptogenic epilepsy patients recorded a significant and greater percentage of anti T. gondii IgG antibodies (54\%) as compared to $22 \%$ in known-cause epilepsy patients and $18 \%$ in non-epileptic healthy controls [70]. Similarly, ELISA performed on 22 cryptogenic epilepsy patients revealed that $75 \%$ of these patients had greater $T$. gondii antibody titers than those recorded among the controls [71]. Finally, a meta-analysis study highlighted the increased odds ratio to 1.72 for Toxoplasmosis infection among patients with epilepsy and a significant association between both cryptogenic and active convulsive epilepsy with T. gondii infection [72]. These studies favor a potential association between T. gondii and epilepsy.

\subsubsection{Toxoplasmosis and Parkinson's and Alzheimer's Neuropathies}

Antibodies against Toxoplasma gondii infection were investigated in Parkinson's and Alzheimer's patients. No significant association was reported between toxoplasmosis and Parkinson's disease [73,74]. Seroprevalence for T. gondii was significantly higher in Alzheimer's patients as compared to their matched controls [75-77]. Importantly, Alzheimer's patients did not witness reactivation of latent toxoplasmosis, with only one case over 105 patients exhibiting positive IgM [78]. Yet, in a meta-analysis on observational studies between $T$. gondii infection and Alzheimer's disease, only a marginally significant association was noted [73]. At the molecular level, 118 genes (around 27.3\%) over 432 susceptibility genes in Alzheimer's disease are involved in the T. gondii host/pathogen interactome [79]. In preclinical models, experiments on BALB/c mice showed that infection with $T$. gondii leads to Alzheimer's-like symptoms including conflicts in learning and weak memory [80]. In C57BL/ 6 mice, an accumulation of beta amyloid (A $\beta$ ) immunoreactivity and hyperphosphorylated tau, one of the markers of Alzheimer's disease, was recorded in the brains of mice [81]. Another study reported that Toxoplasma infection ameliorates $\beta$-amyloidosis in a murine model of Alzheimer's disease. This was mostly due to the activation and recruitment of monocytes, hence enhancing the degradation of soluble $A \beta$ [82]. The effect of the immunosuppression induced by T. gondii infection on the pathophysiology of Alzheimer's disease was also addressed in a murine model of Alzheimer's disease (Tg2576). While IFN- $\gamma$ levels remained unchanged, the levels of anti-inflammatory cytokines were significantly higher in T. gondii-infected mice than in uninfected mice. Furthermore, $\beta$-amyloid plaque deposition in the cortex and hippocampus was remarkably 
lower and better cognitive capacities were observed in T. gondii-infected mice, demonstrating a positive impact of T. gondii-induced immunosuppression on Alzheimer's progression in a murine model [83]. Given that the progression of Alzheimer's disease deteriorates upon the accumulation of $\mathrm{A} \beta$ plaques, which are eliminated through microglial phagocytosis, the association between microglial proliferation and $A \beta$ plaque burden using brain tissues isolated from an Alzheimer's disease murine model (5XFAD) following infection with T. gondii was studied. In the infected group, a significant decrease in the amyloid plaque burden concurrent with an extensive proliferation of homeostatic microglial proliferation and an increased number of plaque-associated microglia were observed. Hence, it was concluded that chronic T. gondii infection can induce microglial proliferation in the brains of mice with progressed Alzheimer's disease, a promising approach for the treatment of this neuropathy [84]. In conclusion, the relationship of T. gondii and the development of Alzheimer's disease and cognitive impairment require further studies on human subjects and animal models [85] to elucidate the possible role of toxoplasmosis in the etiology of Alzheimer's disease.

\subsection{Toxoplasma gondii, Psychiatric and Behavioral Disorders}

One of the mechanisms ensuring T. gondii expansion throughout its life cycle involves behavioral changes between intermediate and final hosts. Indeed, behavioral peculiarities were reported in infected rodents, which exhibit attenuated aversion and fear and do not flee cats' urine odor (reviewed in [86]). In humans, an increasing body of literature indicates that chronic toxoplasmosis is associated with aberrant host behavior [87] and influences the progression of psychiatric disorders [88], such as schizophrenia, bipolar disorder, and obsessive compulsive disorder $[89,90]$ (Figure 3). This is partly due to altered dopamine levels following T. gondii infection [91-94]. The mechanisms underpinning these changes are still vague and complex, and seem to involve the immune response, hormonal changes, genetic and epigenetic factors as well as structural effects on the infected area of the brain.

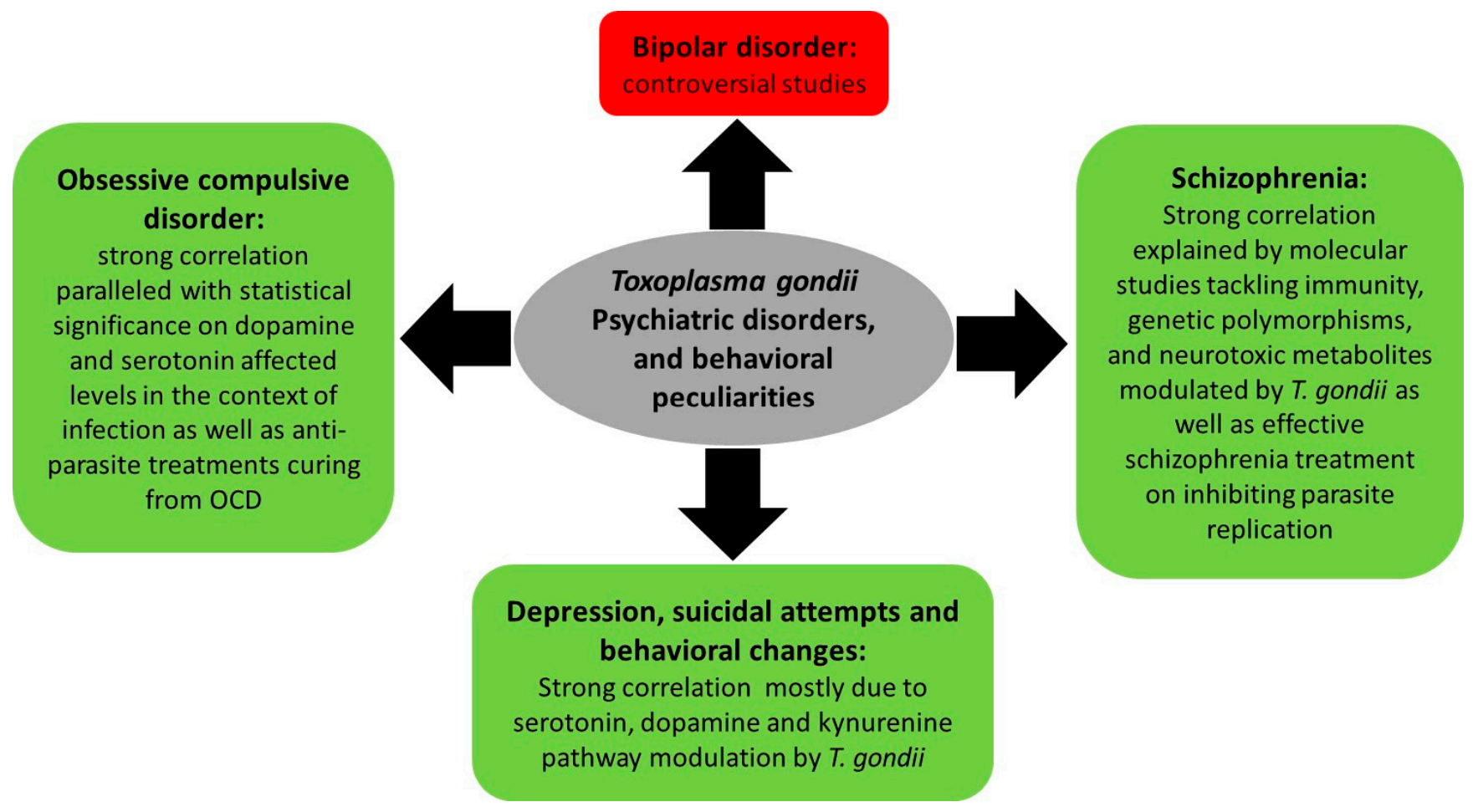

Figure 3. Summary of Toxoplasma gondii-associated psychiatric and behavioral disorders and the molecular status dictating these associations. 


\subsubsection{Toxoplasmosis, Depression, and Behavioral Changes}

Depression, a mood disorder [95], is characterized by altered levels of serotonin and dopamine. Decreased levels of serotonin are at the cornerstone of depression. Tryptophan, serotonin's precursor, is essential for Toxoplasma growth [96,97]. T. gondii infection triggers inflammatory molecules such as IL-2, IFN- $\gamma$, and TNF- $\alpha$, which consequently upregulate IDO and TDO, hence shunting tryptophan into a degradation pathway. Tryptophan is degraded into kynurenine by indoleamine-2,3-dioxygenase (IDO) and tryptophan-2,3-dioxygenase (TDO). The depletion of tryptophan promotes the onset of depression [98-101].

The kynurenine pathway is known to produce neurotoxic metabolites such as kynurenic acid (KYNA), quinolinic acid (QUIN), and 3-hydroxykynurenine. This pathway is activated during Toxoplasma infection, and abnormal levels of KYNA were reported in preclinical mouse models of T. gondii as well as in subjects infected with this parasite [102,103]. While abnormal levels of KYNA were shown to decrease both dopamine and glutamate extracellular concentrations in rodent models [104], T. gondii infection does not seem to exhibit same effect. Indeed, it was reported that $T$. gondii tyrosine and phenylalanine hydroxylase genes catalyze tyrosine and phenylalanine, both of which are precursors of dopamine [105], which may lead to increased dopamine levels and presumably less depression symptoms. In humans, studies demonstrated that chronic toxoplasmosis is associated with systematic changes in human personality [106]. A study enrolling 285 participants revealed that depressed individuals who attempted suicide exhibited higher $T$. gondii IgG titers than those who did not [107]. Elderly women (aged 60 or above) are more prone to suicidal attempts when seropositive for T. gondii [108]. A detailed review involving three wide metaanalyses in different European countries on the associations between T. gondii serology and suicidal behavior reported a 39 to $57 \%$ elevation of odds of suicide attempts in T. gondii IgG-positive patients [109]. One case report showed that a depressed 32-year-old male did not respond to antidepressant therapy until he was treated for acute toxoplasmosis, suggesting a probable association between toxoplasmosis and depression [110].

\subsubsection{Toxoplasmosis and Schizophrenia}

Schizophrenia is a psychiatric disorder encompassing varying degrees of delusions, disorganized thoughts, hallucinations that are mainly auditory, disorganized behaviors, and negative symptoms such as having a blunted affect. Difficulties in social interactions, emotions, and overall functionality are also noticed. Different studies associated T. gondii infections with schizophrenia. It was indeed reported that chronic toxoplasmosis associated with schizophrenia is characterized by a significant reduction in gray matter; a finding not seen in the control groups [111]. Different studies investigated the association between toxoplasmosis and schizophrenia. The first meta-analysis in that regard was performed in 2007 and updated 5 years later [112,113], and revealed significantly elevated seropositive rates of anti-Toxoplasma IgG and IgM in schizophrenic patients. Similar results were obtained on around 800 Chinese patients with schizophrenia as compared to their matching controls [114], and in a large case-control study on around 80,000 individuals, where T. gondii IgG titers were detected in the plasma samples of $25 \%$ of patients and were significantly associated with schizophrenia [115]. Genetic susceptibility is one of the main risk factors to develop schizophrenia. It was reported that people infected with T. gondii and suffering from schizophrenia have polymorphisms in genes encoding glucocorticoid-inducible kinase 1 (SGK1) and solute carrier family 2 member 12 (SLC2A12), supporting the plausible role of inflammatory processes and infections as risk factors for psychotic behaviors [116], but these associations did not achieve statistical significance on a genome-wide level [116]. Moreover, $T$. gondii infection represents a risk factor to develop schizophrenia in susceptible individuals or to exacerbate disease progression, but T. gondii alone does not trigger schizophrenia, leading to hippocampal pathologies and increased KYNA levels, which decrease dopamine and glutamate, thus altering cognitive functions [101], and leading to the production of neurotoxic metabolites such as quinolinic 
acid and 3-hydroxykynurenine $[117,118]$. At the molecular level, a major mental illnessrelated susceptibility factor, the "Disrupted in schizophrenia" (DISC1), is involved in host immune responses against $T$. gondii infection, and certain genotypes of DISC1, particularly the 607 Phe/Phe, correlate with higher serology against this parasite [119]. Furthermore, decreased $C D 8^{+} \mathrm{T}$ activity and loss of their proliferation and cytokine secretion potentially increase the risk of schizophrenia as a result of focal necrosis and inflammation. It is important to recall that $\mathrm{CD} 8^{+} \mathrm{T}$ cell numbers, which play a crucial role in fighting $T$. gondii infections, are decreased in schizophrenic patients [120,121]. Finally, some medications used to treat schizophrenia inhibited the replication of T. gondii in cell culture [122].

\subsubsection{Toxoplasmosis and Bipolar Disorder}

Bipolar disorder (BD), known as manic depression, is a psychiatric disorder in which the patient suffers from rapid or sudden mood changes fluctuating between extreme euphoria to extreme sadness and depression. The etiology of BD is complex and encompasses brain and peripheral chronic inflammation, immune dysfunction, genetic inheritance, and environmental risk factors. Different correlation studies were conducted between toxoplasmosis and bipolar disorders and were contentious. While some studies revealed an increased prevalence of T. gondii in these individuals [123-126], other studies showed no correlation [127,128]. In BD patients infected with T. gondii, increased levels of kynurenine and kynurenic acid are documented, which correlates with fluctuating levels of dopamine and glutamate as well as the production of neurotoxic factors [104].

\subsubsection{Toxoplasmosis and Obsessive Compulsive Disorder}

According to the World Health Organization, obsessive compulsive disorder (OCD) is a mental disorder ranked among the top ten life-quality-reducing mental disorders. People with OCD cannot control their thoughts and obsessively repeat activities such as washing hands, checking doors, among others. A meta-analysis pooling 11 studies (9873 participants, including 389 OCD patients) showed a strong correlation between the prevalence of toxoplasmosis and OCD, with a statistically significant odds ratio of correlation with increased dopamine levels [129]. Other studies suggest that toxoplasmosis leads to changes in hypothalamic-pituitary-adrenal gland axis activity and hormonal disorders including serotonin, which can also lead to OCD [130]. The treatment of two children diagnosed with OCD and seropositive for $T$. gondii with anti-protozoan medication resulted in both decreased levels of antibodies and a total cure from OCD [131].

\subsection{Toxoplasma gondii and Cancers: Modulation of miRNAs as One Molecular Explanation of Toxoplasma-Associated Brain Cancers}

Different types of cancers, especially brain cancers, are associated with T. gondii infection. Indeed, the incidence of adult brain cancers is higher in countries with common infection with T. gondii [132-135]. This positive correlation was associated with the ability of the parasite to interfere with the brain cells' miRNAome [135], which might lead to brain tumor development [136]. Beyond brain cancers, higher anti-T. gondii antibodies were observed in various types of cancer including lung, prostate, cervix, and endometrial cancers [134,137-139].

T. gondii alters the expression of crucial miRNAs responsible for mounting an immune response in the host cell against the infection [140]. These miRNAs target many transcripts associated with immune functions, such as cytokines, chemokines, and interleukins. Studies have focused on global host miRNA responses following T. gondii infection in multiple cell types such as human foreskin fibroblasts (HFFs) and neuro-epithelial cells in various regions in the body such as the brain, plasma, spleen, and liver. The miR-17-92 cluster, one of the upregulated miRNAs during infection [141], inhibits host cell apoptosis, a survival strategy of Toxoplasma [142,143]. miR-132 is a small endogenous cyclic AMP-responsive element binding (CREB)-regulated miRNA known to have both immune and neural functions. Several neurological disorders were associated with the dysregulation of miR-132, including Toxoplasma-induced encephalopathy, Alzheimer's disease, Parkinson's disease, 
epilepsy, depression, and schizophrenia [144]. Likewise, infected neuro-epithelioma cells with different types of $T$. gondii strains showed an upregulation of miR-132 involved in the signaling of dopamine receptors by more than two-fold [145].

In humans, several studies validated the expression of miRNA in brain tumors including glioblastoma, pituitary adenoma, and medulloblastoma compared to other tissues [146-148]. Ryan et al.'s studies showed that in the case of meningioma, there is a noticeable level of antibodies for Toxoplasma [133]. A meta-analysis study including 37 countries showed that in areas of high prevalence of Toxoplasma infection, there is approximately a two-fold increase in brain cancer risk, suggesting the association between Toxoplasma occurrence and adult brain cancers [134]. Another epidemiological study revealed that rates of death in brain cancer are positively correlated with sero-prevalence for Toxoplasma, especially for people who are aged 55 years or older [149]. Primary human astrocytic glioma tissue specimens over-express the miR-17-92 cluster compared to nonneoplastic brain control tissues $[150,151]$. During infection, a decrease in phosphatase and tensin homolog (PTEN) in brain cells by miR-17-92 activated the AKT pathway, which promotes survival and growth in response to extracellular signals, resulting in brain cancer development [152]. Considering the significance of miRNAs in the development of brain carcinogenesis, it is worth noting that the Toxoplasma genome codes for ostentatious RNA silencing machinery and endogenous small silencing RNAs, including miRNAs [153].

\section{Current Treatments}

The treatment of toxoplasmosis remains limited to relatively general anti-parasitic/ anti-bacterial drugs (reviewed $[154,155]$ ). These include spiramycin, azithromycin, atovaquone, pyrimethamine-sulfadiazine, pyrimethamine-clindamycin, and trimethoprimsulfamethoxazole. Unlike its mammalian host, T. gondii is unable to use preformed dietary folates and has to synthesize folates de novo [156]. Thus, the recommended first-line therapy remains the synergistic combination of pyrimethamine, an inhibitor of dihydrofolate reductase (DHFR) enzyme, and sulfadiazine, an inhibitor of dihydropteroate synthase [156-158]. This combination is usually administered with folinic acid (leucovorin) to reduce harmful side effects, amongst which is bone marrow suppression [159]. The aforementioned combination blocks the biosynthesis of parasitic folate, thus interrupting nucleic acid synthesis and parasite replication. However, this combination is associated with several limitations, including but not limited to hematological side effects such as neutropenia, thrombocytopenia, and leukopenia [160]. Other side effects include an elevation in serum creatinine and serum liver enzymes, hypersensitivity or allergic reactions [161], and the emergence of resistant strains [162,163], especially in immunocompromised patients [164]. Pyrimethamine can potentially be teratogenic and should not be used during the early months of pregnancy [164]. These drugs, whether given prophylactically or therapeutically, target only the acute phase of the infection and remain useless against the chronic form of toxoplasmosis represented by tissue cysts [165]. To date, there is no approved therapy that eliminates the tissue cysts responsible for the chronic stage of Toxoplasma infection [162,166,167]. Degerli et al. evaluated the effectiveness of azithromycin, a protein synthesis inhibitor, in a preclinical mouse model infected with $T$. gondii tachyzoites and following the development of bradyzoite stages. The study showed that the drug is effective both prophylactically and during the early stages of infection [168]. In pregnant women, treatment is based on the administration of spiramycin or sulfadiazine-pyrimethamine-folinic acid (SPFA) if fetal infection is confirmed [168].

In a systematic review, Montazeri et al. evaluated the in vitro and in vivo activities of anti-Toxoplasma drugs and compounds during the time period between 2006 and 2016. Eighty clinically available drugs and a large number of new compounds with more than forty mechanisms of action were summarized. Several target-based drug screens were also identified, including mitochondrial electron transport chain, calcium-dependent protein kinase 1, type II fatty acid synthesis, DNA synthesis, and DNA replication, among several others [167]. Most of these drugs are effective against tachyzoites, and only very few trigger bradyzoites or the back and forth switch between both stages [167]. It is worth 
noting that an ideal drug against toxoplasmosis should not only be effective against the proliferative tachyzoite stage of the parasite but also against the tissue cyst stage, particularly since the chronic form is the most prevalent among all diseases caused by and associated with this parasitic infection. In addition, these drugs should be able to cross the blood brain barrier and penetrate the brain, where the accumulation of bradyzoite cysts is high [169]. Recently, the effect of imiquimod, an efficient immunomodulatory drug, was explored in murine models of acute and chronic toxoplasmosis. Treatment with imiquimod during acute toxoplasmosis reduced the number of brain cysts while rendering the remaining ones un-infectious. Importantly, treatment with imiquimod, postestablishment of CT, significantly reduces the number of brain cysts, leading to a delay or abortion of reactivation. Molecularly, imiquimod upregulated the expression of Toll-like receptors and activated the MyD88 pathway, resulting in the induction of the immune response to control reactivation [170].

\section{Toxoplasmosis and Prophylaxis: Available and Potential Vaccine Strategies}

Due to the burdensome effects of toxoplasmosis and the failure and/or adverse effects of the currently used therapeutic approaches, several attempts were made to develop vaccines against T. gondii (for a review, see [171]). In 1995, the first commercial vaccine for toxoplasmosis, Ovilis Toxovax, was developed. It consisted of an injectable suspension of attenuated parasites of the strain S48, originally isolated from a case of ovine abortion in New Zealand. Following approximately 3000 passages in mice, this strain lost its ability to differentiate into tissue cysts in mice and into oocysts in cats $[172,173]$. This live vaccine was used to prevent toxoplasmosis-induced abortions in sheep, but did not reach human trials due to the high capacity of the parasite to revert back to its pathogenic features. Other vaccine candidates were tested, including apical complex proteins from T. gondii (rhoptries, micronemes, and dense granules), multi-antigen vaccines, and other adjuvants $[174,175]$. However, these attempts failed to yield proper protection against toxoplasmosis in humans [176]. In addition, some classes of antigens were proposed to be potential vaccine candidates. These include the Recombinant Surface Antigen-1 (SAG-1), which is a GPI-anchored and highly immunogenic surface marker of the tachyzoite stage of T. gondii and which may protect against acute toxoplasmosis $[177,178]$ and thus brain cyst formation $[179,180]$. Recombinant GRA4 and ROP2 given with Alum adjuvant were also proposed and provided protection against brain cyst formation in C57BL/6 mice [181]. A mixture of SAG1, GRA1, and Merozoite Antigen-1 (MAG1), given with Freund's Complete Adjuvant, reduced brain cyst burden by $90 \%$ in BALB/c mice. A mixture of GERBU, an adjuvant based on cationic lipid solid nanoparticles and NacetylglucosaminylN-acetylmuramyl-l-alanyl-d-isoglutamine, a glycopeptide derived from Lactobacillus bulgaricus cell walls, with GRA7 and a MIC2-MIC3-SAG1 chimeric protein provided an $80 \%$ reduction in brain cysts in outbred SWISS mice following challenge with $T$. gondii 76K [182,183]. Finally, the double knock-out of MIC1-MIC3 genes markedly impaired virulence and conferred protection from T. gondii [184].

An ideal vaccine must possess different antigens from all three infective stages of $T$. gondii to increase the ability of inducing a strong immune response [185]. Vaccine development proposed multi-epitope DNA vaccines composed of $\mathrm{CD}^{+} \mathrm{T}$ cell-eliciting, rhomboid protease 4 and GRA14 of the RH strain, as well as CD4 ${ }^{+}$helper T lymphocyte epitope(s) administered with lipid adjuvant [184], coated with calcium phosphate nanoparticles [186] or recombinant proteins formulated in Poly (DL-lactide-co-glycolide) microspheres [187], or virus-like particles (VLPs) [188]. These multi-epitope vaccine attempts increased both the cellular and humoral responses by the augmentation of memory $\mathrm{CD}^{+} \mathrm{T}$ cells, thus inducing a higher IFN- $\gamma$ production, and protected mice against parasite burden when challenged with T. gondii.

Altogether, and beyond the Toxovax vaccine used on sheep, these studies remain limited to rodents and require more investigation to come up with an ideal vaccine of Toxoplasma for clinical trials. 


\section{Concluding Remarks}

Despite its prevalence, toxoplasmosis remains a neglected disease. Increased statistical correlations between toxoplasmosis and neurologic, psychiatric, and cancer disorders have been unveiled. Addressing the molecular players underlying these associations is paramount in creating avenues for new treatment modalities, especially in light of the absence of a gold standard treatment and a human vaccine against toxoplasmosis. To reach this aim, establishing appropriate animal models of primary neuropathies and behavioral disorders is a must. Indeed, some available pre-clinical models recapitulate the features of some of these diseases, but the absence of the appropriate model remains a challenge for most of them. The recent advances in high-throughput sequencing and proteomics techniques should help in apprehending the correct molecular markers and biomarkers between the parasite and its associated diseases. In addition, the ease of genetic manipulation using multiple tools, including the CRISPR-cas9 targeted disruption or knock-in for genes in T. gondii, will help increase our understanding of the molecular players to confirm the positive correlations between toxoplasmosis and primary neuropathies/associated diseases and solve the enigma of the available controversial studies. Finally, clinicians should increase their awareness of reactivation in immunocompromised patients, an area of interest in which quick molecular diagnostic tests are still lacking.

Author Contributions: D.D., A.S., E.S., M.H., M.E.H., M.B.M., S.I., R.E.H., L.T., M.E.S. and H.E.H. contributed to the write up of this review. All authors have read and agreed to the published version of the manuscript.

Funding: This research received no external funding.

Institutional Review Board Statement: Not applicable.

Informed Consent Statement: Not applicable.

Data Availability Statement: Not applicable.

Acknowledgments: Not applicable.

Conflicts of Interest: The authors declare no conflict of interest.

\section{References}

1. Skariah, S.; McIntyre, M.K.; Mordue, D.G. Toxoplasma gondii: Determinants of tachyzoite to bradyzoite conversion. Parasitol. Res. 2010, 107, 253-260. [CrossRef]

2. Robert-Gangneux, F.; Dardé, M.-L. Epidemiology of and Diagnostic Strategies for Toxoplasmosis. Clin. Microbiol. Rev. 2012, 25, 264. [CrossRef]

3. Ben-Harari, R.R.; Connolly, M.P. High burden and low awareness of toxoplasmosis in the United States. Postgrad. Med. 2019, 131, 103-108. [CrossRef]

4. Montoya, J.G.; Liesenfeld, O. Toxoplasmosis. Lancet 2004, 363, 1965-1976. [CrossRef]

5. Reza Yazdani, M. Frequency of sero-positivity in household members of the patients with positive toxoplasma serology. Rev. Esp. Quimioter. 2018, 31, 506-510. [PubMed]

6. Sibley, L.D.; Boothroyd, J.C. Virulent strains of Toxoplasma gondii comprise a single clonal lineage. Nature 1992, 359 , 82-85. [CrossRef]

7. Mendez, O.A.; Koshy, A.A. Toxoplasma gondii: Entry, association, and physiological influence on the central nervous system. PLoS Pathog. 2017, 13, e1006351. [CrossRef] [PubMed]

8. Lambert, H. Induction of dendritic cell migration upon Toxoplasma gondii infection potentiates parasite dissemination. Cell Microbiol. 2006, 8, 1611-1623. [CrossRef] [PubMed]

9. Lachenmaier, S.M.; Deli, M.A.; Meissner, M.; Liesenfeld, O. Intracellular transport of Toxoplasma gondii through the blood-brain barrier. J. Neuroimmunol. 2011, 232, 119-130. [CrossRef] [PubMed]

10. Ueno, N.; Harker, K.S.; Clarke, E.C.; McWhorter, F.Y.; Liu, W.F.; Tenner, A.J.; Lodoen, M.B. Real-time imaging of Toxoplasmainfected human monocytes under fluidic shear stress reveals rapid translocation of intracellular parasites across endothelial barriers. Cell Microbiol. 2014, 16, 580-595. [CrossRef] [PubMed]

11. Courret, N.; Darche, S.; Sonigo, P.; Milon, G.; Buzoni-Gâtel, D. Isabelle Tardieux CD11c- and CD11b-expressing mouse leukocytes transport single Toxoplasma gondii tachyzoites to the brain. Blood 2006, 107, 309-316. [CrossRef] [PubMed]

12. Dobrowolski, J.M.; Sibley, L.D. Toxoplasma invasion of mammalian cells is powered by the actin cytoskeleton of the parasite. Cell 1996, 84, 933-939. [CrossRef] 
13. Lindsay, D.S.; Dubey, J.P. Toxoplasma gondii: The changing paradigm of congenital toxoplasmosis. Parasitology 2011, $138,1829-1831$. [CrossRef] [PubMed]

14. Yamamoto, L.; Targa, L.S.; Sumita, L.M.; Shimokawa, P.T.; Rodrigues, J.C.; Kanunfre, K.A.; Okay, T.S. Association of Parasite Load Levels in Amniotic Fluid With Clinical Outcome in Congenital Toxoplasmosis. Obstet. Gynecol. 2017, 130, 335-345. [CrossRef] [PubMed]

15. Robert-Gangneux, F.; Murat, J.B.; Fricker-Hidalgo, H.F.; Brenier-Pincat, M.-P.; Gangneux, J.-P.; Pelloux, H. The placenta: A main role in congenital toxoplasmosis? Trends Parasitol. 2011, 27, 530-536. [CrossRef] [PubMed]

16. McAuley, J.B. Congenital Toxoplasmosis. J. Pediatric Infect. Dis. Soc. 2014, 3, S30-S35. [CrossRef]

17. Singh, S. Congenital toxoplasmosis: Clinical features, outcomes, treatment, and prevention. Trop. Parasitol. 2016, 6, 113-122. [CrossRef]

18. Weiss, L.M.; Dubey, J.P. Toxoplasmosis: A history of clinical observations. Int. J. Parasitol. 2009, 39, 895-901. [CrossRef]

19. Nowakowska, D.; Stray-Pedersen, B.; Spiewak, E.; Sobala, W.; Małafiej, E.; Wilczyński, J. Prevalence and estimated incidence of Toxoplasma infection among pregnant women in Poland: A decreasing trend in the younger population. Clin. Microbiol. Infect. 2006, 12, 913-917. [CrossRef]

20. Nahouli, H.; Arnaout, N.E.; Chalhoub, E.; Anastadiadis, E.; Hajj, H.E. Seroprevalence of Anti-Toxoplasma gondii Antibodies Among Lebanese Pregnant Women. Vector Borne Zoonotic Dis. 2017, 17, 785-790. [CrossRef]

21. Galal, L.; Sarry, A.; Cuny, T.; Brouat, C.; Coulibaly, F.; Sembène, M.; Diagne, M.; Diallo, M.; Sow, A.; Hamidović, A.; et al. The introduction of new hosts with human trade shapes the extant distribution of Toxoplasma gondii lineages. PLoS Negl. Trop. Dis. 2019, 13, e0007435. [CrossRef] [PubMed]

22. Delhaes, L.; Ajzenberg, D.; Sicot, B.; Bourgeot, P.; Dardé, M.-U.; Dei-Cas, E.; Houfflin-Debarge, V. Severe congenital toxoplasmosis due to a Toxoplasma gondii strain with an atypical genotype: Case report and review. Prenat. Diagn. 2010, 30, 902-905. [CrossRef] [PubMed]

23. Vallochi, A.L.; Goldberg, A.C.; Angela Falcai, A.; Ramasawmy, R.; Jorge Kalil, J.; Silveira, C.; Belfort, R.; Rizzo, L.V. Molecular markers of susceptibility to ocular toxoplasmosis, host and guest behaving badly. Clin. Ophthalmol. 2008, 2, 837-848. [CrossRef] [PubMed]

24. Atmaca, L.S.; Simsek, T.; Batioglu, F. Clinical features and prognosis in ocular toxoplasmosis. Jpn. J. Ophthalmol. 2004, 48, 386-391. [CrossRef] [PubMed]

25. Delair, E.; Latkany, P.; Noble, A.G.; Rabiah, P.; McLeod, R.; Brezin, A. Clinical manifestations of ocular toxoplasmosis. Ocul. Immunol. Inflamm. 2011, 19, 91-102. [CrossRef]

26. Vasconcelos-Santos, D.V.; Dodds, E.M.; Orefice, F. Review for disease of the year: Differential diagnosis of ocular toxoplasmosis. Ocul. Immunol. Inflamm. 2011, 19, 171-179. [CrossRef]

27. Sauer, A.; Rochet, E.; Lahmar, I.; Brunet, J.; Sabou, M.; Bourcier, T.; Candolfi, E.; Pfaff, A.W. The local immune response to intraocular Toxoplasma re-challenge: Less pathology and better parasite control through Treg/Th1/Th2 induction. Int. J. Parasitol. 2013, 43, 721-728. [CrossRef]

28. Schlüter, D.; Barragan, A. Advances and Challenges in Understanding Cerebral Toxoplasmosis. Front. Immunol. 2019, 10, 242. [CrossRef]

29. Blanchard, N.; Dunay, I.R.; Schlüter, D. Persistence of Toxoplasma gondii in the central nervous system: A fine-tuned balance between the parasite, the brain and the immune system. Parasite Immunol. 2015, 37, 150-158. [CrossRef]

30. Matta, S.K.; Rinkenberger, N.; Dunay, I.R.; Sibley, L.D. Toxoplasma gondii infection and its implications within the central nervous system. Nat. Rev. Microbiol. 2021, 19, 467-480. [CrossRef]

31. Harker, K.S.; Ueno, N.; Wang, T.; Bonhomme, C.; Liu, W.; Lodoen, M.B. Toxoplasma gondii modulates the dynamics of human monocyte adhesion to vascular endothelium under fluidic shear stress. J. Leukoc. Biol. 2013, 93, 789-800. [CrossRef]

32. Torgerson, P.R.; Devleesschauwer, B.; Praet, N.; Speybroeck, N.; Willingham, A.L.; Kasuga, F.; Rokni, M.B.; Zhou, X.; Fèvre, E.M.; Sripa, B.; et al. World Health Organization Estimates of the Global and Regional Disease Burden of 11 Foodborne Parasitic Diseases, 2010: A Data Synthesis. PLoS Med. 2015, 12, e1001920. [CrossRef] [PubMed]

33. Cekanaviciute, E.; Dietrich, H.K.; Axtell, R.C.; Williams, A.M.; Egusquiza, R.; Wai, K.M.; Koshy, A.A.; Buckwalter, M.S. Astrocytic TGF-beta signaling limits inflammation and reduces neuronal damage during central nervous system Toxoplasma infection. $J$. Immunol. 2014, 193, 139-149. [CrossRef] [PubMed]

34. Halonen, S.K.; Chiu, F.; Weiss, L.M. Effect of cytokines on growth of Toxoplasma gondii in murine astrocytes. Infect. Immun. 1998, 66, 4989-4993. [CrossRef]

35. Miller, K.D.; Schnell, M.J.; Rall, G.F. Keeping it in check: Chronic viral infection and antiviral immunity in the brain. Nat. Rev. Neurosci. 2016, 17, 766-776. [CrossRef]

36. Schluter, D.; Deckert, M.; Hof, H.; Frei, K. Toxoplasma gondii infection of neurons induces neuronal cytokine and chemokine production, but gamma interferon and tumor necrosis factor-stimulated neurons fail to inhibit the invasion and growth of T. gondii. Infect. Immun. 2001, 69, 7889-7893. [CrossRef] [PubMed]

37. Suzuki, Y.; Conley, F.K.; Remington, J.S. Importance of endogenous IFN-gamma for prevention of toxoplasmic encephalitis in mice. J. Immunol. 1989, 143, 2045-2050. 
38. Evans, A.K.; Strassmann, P.S.; Lee, I.P.; Sapolsky, R.M. Patterns of Toxoplasma gondii cyst distribution in the forebrain associate with individual variation in predator odor avoidance and anxiety-related behavior in male Long-Evans rats. Brain Behav. Immun. 2014, 37, 122-133. [CrossRef]

39. Hermes, G.; Ajioka, J.W.; Kelly, K.A.; Mui, E.; Roberts, F.; Kasza, K.; Mayr, T.; Kirisits, M.J.; Wollmann, R.; Ferguson, D.J.P.; et al. Neurological and behavioral abnormalities, ventricular dilatation, altered cellular functions, inflammation, and neuronal injury in brains of mice due to common, persistent, parasitic infection. J. Neuroinflamm. 2008, 5, 48. [CrossRef]

40. Xiao, J.; Li, Y.; Gressitt, K.L.; He, H.; Kannan, G.; Schultz, T.L.; Svezhova, N.; Carruthers, V.B.; Pletnikov, M.V.; Yolken, R.H.; et al. Cerebral complement C1q activation in chronic Toxoplasma infection. Brain Behav. Immun. 2016, 58, 52-56. [CrossRef]

41. David, C.N.; Frias, E.S.; Szu, J.I.; Vieira, P.A.; Hubbard, J.A.; Lovelace, J.; Michael, M.; Worth, D.; McGovern, K.E.; Ethell, I.M.; et al. GLT-1-Dependent Disruption of CNS Glutamate Homeostasis and Neuronal Function by the Protozoan Parasite Toxoplasma gondii. PLoS Pathog. 2016, 12, e1005643. [CrossRef]

42. Parlog, A.; Harsan, L.A.; Zagrebelsky, M.; Weller, M.; Elverfeldt, D.V.; Mawrin, C.; Korte, M.; Dunay, I.R. Chronic murine toxoplasmosis is defined by subtle changes in neuronal connectivity. Dis. Models Mech. 2014, 7, 459. [CrossRef]

43. Johnson, H.J.; Koshy, A.A. Latent Toxoplasmosis Effects on Rodents and Humans: How Much is Real and How Much is Media Hype? mBio 2020, 11. [CrossRef]

44. Johnson, S.K.; Johnson, P.T.J. Toxoplasmosis: Recent Advances in Understanding the Link Between Infection and Host Behavior. Annu. Rev. Anim. Biosci. 2021, 9, 249-264. [CrossRef]

45. Gharamti, A.A.; Rao, A.; Pecen, P.E.; Henao-Martínez, A.F.; Franco-Paredes, C.; Montoya, J.G. Acute Toxoplasma Dissemination With Encephalitis in the Era of Biological Therapies. Open Forum. Infect. Dis. 2018, 5, 256-259. [CrossRef]

46. Bannoura, S.; El Hajj, R.; Khalifeh, I.; El Hajj, H. Acute disseminated encephalomyelitis and reactivation of cerebral toxoplasmosis in a child: Case report. IDCases 2018, 13, e00434. [CrossRef]

47. Basavaraju, A. Toxoplasmosis in HIV infection: An overview. Trop. Parasitol. 2016, 6, 129-135. [CrossRef]

48. Kodym, P.; Malý, M.; Beran, O.; Jilich, D.; Rozsypal, H.; Machala, L.; Holub, M. Incidence, immunological and clinical characteristics of reactivation of latent Toxoplasma gondii infection in HIV-infected patients. Epidemiol. Infect. 2015, 143, 600-607. [CrossRef]

49. Gay, J.; Gendron, N.; Verney, C.; Joste, V.; Dardé, M.L.; Loheac, C.; Vrtovsnik, F.; Argy, N.; Houze, S. Disseminated toxoplasmosis associated with hemophagocytic syndrome after kidney transplantation: A case report and review. Transpl. Infect. Dis. 2019, 21, e13154. [CrossRef]

50. Kollu, V.; Magalhaes-Silverman, M.; Tricot, G.; Ince, D. Toxoplasma Encephalitis following Tandem Autologous Hematopoietic Stem Cell Transplantation: A Case Report and Review of the Literature. Case Rep. Infect. Dis. 2018. [CrossRef]

51. Paccoud, O.; Guitard, J.; Labopin, M.; Surgers, L.; Malard, F.; Battipaglia, G.; Duléry, R.; Hennequin, C.; Mohty, M.; Brissot, E. Features of Toxoplasma gondii reactivation after allogeneic hematopoietic stem-cell transplantation in a high seroprevalence setting. Bone Marrow Transpl. 2020, 55, 93-99. [CrossRef]

52. Ramanan, P.; Scherger, S.; Benamu, E.; Bajrovic, V.; Jackson, W.; Hage, C.A.; Hakki, M.; Baddley, J.W.; Abidi, M.Z. Toxoplasmosis in non-cardiac solid organ transplant recipients: A case series and review of literature. Transpl. Infect. Dis. 2020, 22 , e13218. [CrossRef] [PubMed]

53. Ramchandar, N.; Pong, A.; Anderson, E. Identification of disseminated toxoplasmosis by plasma next-generation sequencing in a teenager with rapidly progressive multiorgan failure following haploidentical stem cell transplantation. Pediatr. Blood Cancer 2020, 67, e28205. [CrossRef] [PubMed]

54. Robert-Gangneux, F.; Meroni, V.; Dupont, D.; Botterel, F.; Garcia, J.M.A.; Brenier-Pinchart, M.P.; Accoceberry, I.; Akan, H.; Abbate, I.; Boggian, K.; et al. Toxoplasmosis in Transplant. Recipients, Europe. 2010-2014. Emerg. Infect. Dis. 2018, 24, 1497-1504. [CrossRef] [PubMed]

55. Rajapakse, S.; Weeratunga, P.; Rodrigo, C.; Lakshitha de Silva, N.; Fernando, S.D. Prophylaxis of human toxoplasmosis: A systematic review. Pathog. Glob. Health 2017, 111, 333-342. [CrossRef]

56. Li, Y.; Zeng, Y.-M.; Liu, M.; Lu, Y.-Q.; Liu, X.-Y.; Zhang, Y.-L.; Jiang, Z.-S.; Yang, T.-T.; Sun, Y.; Lan, K.; et al. Development of a risk scoring system for prognostication in HIV-related toxoplasma encephalitis. BMC Infect. Dis. 2020, 20, 923. [CrossRef]

57. Holland, M.S.; Sharma, K.; Lee, B.C. Cerebral toxoplasmosis after rituximab therapy for splenic marginal zone lymphoma: A case report and review of the literature. JMM Case Rep. 2015, 2. [CrossRef]

58. Lee, E.B.; Ayoubi, N.; Albayram, M.; Kariyawasam, V.; Motaparthi, K. Cerebral toxoplasmosis after rituximab for pemphigus vulgaris. JAAD Case Rep. 2019, 6, 37-41. [CrossRef]

59. Morjaria, S.; Epstein, D.J.; Romero, F.A.; Taur, Y.; Seo, S.K.; Papanicolaou, G.A.; Hatzoglou, V.; Rosenblum, M.; Perales, M.A.; Scordo, M.; et al. Toxoplasma Encephalitis in Atypical Hosts at an Academic Cancer Center. Open Forum Infect. Dis. 2016, 3. [CrossRef]

60. Safa, G.; Darrieux, L. Cerebral Toxoplasmosis After Rituximab Therapy. JAMA Intern. Med. 2013, 173, 924-926. [CrossRef]

61. La Hoz, R.M.; Morris, M.I. Infectious Diseases Community of Practice of the American Society of, Tissue and blood protozoa including toxoplasmosis, Chagas disease, leishmaniasis, Babesia, Acanthamoeba, Balamuthia, and Naegleria in solid organ transplant recipients-Guidelines from the American Society of Transplantation Infectious Diseases Community of Practice. Clin Transpl. 2019, 33, e13546. 
62. Adekunle, R.O.; Sherman, A.; Spicer, J.O.; Messina, J.A.; Steinbrink, J.M.; Sexton, M.E.; Lyon, G.M.; Mehta, A.K.; Phadke, V.K.; Woodworth, M.H. Clinical characteristics and outcomes of toxoplasmosis among transplant recipients at two US academic medical centers. Transpl. Infect Dis. 2021, 23, e13636. [CrossRef] [PubMed]

63. Madireddy, S.; Rivas Chacon, E.D.; Mangat, R. Toxoplasmosis, in StatPearls; StatPearls Publishing: Treasure Island, FL, USA, 2020.

64. Ngo, H.M.; Zhou, Y.; Lorenzi, H.; Wang, K.; Kim, T.K.; Zhou, Y.; El Bissati, K.; Mui, E.; Fraczek, L.; Rajagopala, S.V.; et al. Toxoplasma Modulates Signature Pathways of Human Epilepsy, Neurodegeneration and Cancer. Sci. Rep. 2017, 7, 11496. [CrossRef]

65. Saberi, R.; Sharif, M.; Sarvi, S.; Aghayan, S.A.; Hosseini, S.A.; Anvari, D.; Chegeni, T.N.; Hosseininejad, Z.; Daryani, A. Is Toxoplasma gondii playing a positive role in multiple sclerosis risk? A systematic review and meta-analysis. J. Neuroimmunol. 2018 322, 57-62. [CrossRef]

66. Nicoletti, A.; Cicero, C.E.; Giuliano, L.; Todaro, V.; Lo Fermo, S.; Chisari, C.; D'Amico, E.; Paradisi, V.; Mantella, A.; Bartoloni, A.; et al. Toxoplasma gondii and multiple sclerosis: A population-based case-Control study. Sci. Rep. 2020, 10, 18855. [CrossRef]

67. Cicero, C.E.; Allibrio, F.E.; Giuliano, L.; Luna, J.; Preux, P.M.; Nicoletti, A. Toxoplasma gondii and multiple sclerosis: A systematic review and meta-analysis. Eur. J. Neurol. 2021. [CrossRef]

68. Ngoungou, E.B.; Bhalla, D.; Nzoghe, A.; Dardé, M.L.; Preux, P.M. Toxoplasmosis and epilepsy-systematic review and meta analysis. PLoS Negl. Trop. Dis. 2015, 9, e0003525. [CrossRef]

69. Bazilevich, S.N. Cryptogenic epilepsy in adults: "hidden problems of structural well-being". Zh. Nevrol. Psikhiatr. Im. S S Korsakova 2013, 113, 10-19. [PubMed]

70. Yazar, S.; Arman, F.; Yalçin, S.; Demirtaş, F.; Yaman, O.; Sahin, I. Investigation of probable relationship between Toxoplasma gondii and cryptogenic epilepsy. Seizure 2003, 12, 107-109. [CrossRef]

71. Stommel, E.W.; Seguin, R.; Thadani, V.M.; Schwartzman, J.D.; Gilbert, K.; Ryan, K.A.; Tosteson, T.D.; Kasper, L.H. Cryptogenic Epilepsy: An. Infectious Etiology? Epilepsia 2001, 42, 436-438. [CrossRef] [PubMed]

72. Sadeghi, M.; Riahi, S.M.; Mohammadi, M.; Saber, V.; Aghamolaie, S.; Moghaddam, S.A.; Aghaei, S.; Javanian, M.; Gamble, H.R.; Rostami, A. An updated meta-analysis of the association between Toxoplasma gondii infection and risk of epilepsy. Trans. R. Soc. Trop Med. Hyg. 2019, 113, 453-462. [CrossRef] [PubMed]

73. Bayani, M.; Riahi, S.M.; Bazrafshan, N.; Gamble, H.R.; Rostami, A. Toxoplasma gondii infection and risk of Parkinson and Alzheimer diseases: A systematic review and meta-analysis on observational studies. Acta Trop. 2019, 196, 165-171. [CrossRef] [PubMed]

74. Mahami Oskouei, M.; Hamidi, F.; Talebi, M.; Farhoudi, M.; Taheraghdam, A.A.; Kazemi, T.; Sadeghi-Bazargani, H.; Fallah, E. The correlation between Toxoplasma gondii infection and Parkinson's disease: A case-control study. J. Parasit. Dis. 2016, 40, 872-876. [CrossRef] [PubMed]

75. Kusbeci, O.Y.; Miman, O.; Yaman, M.; Aktepe, O.C.; Yazar, S. Could Toxoplasma gondii have any role in Alzheimer disease? Alzheimer Dis. Assoc. Disord. 2011, 25, 1-3. [CrossRef] [PubMed]

76. Perry, V.H.; Cunningham, C.; Holmes, C. Systemic infections and inflammation affect chronic neurodegeneration. Nat. Rev. Immunol. 2007, 7, 161-167. [CrossRef]

77. Wyman, C.P.; Gale, S.D.; Hedges-Muncy, A.; Erickson, L.D.; Wilson, E.; Hedges, D.W. Association between Toxoplasma gondii seropositivity and memory function in nondemented older adults. Neurobiol. Aging 2017, 53, 76-82. [CrossRef]

78. Perry, C.E.; Gale, S.D.; Erickson, L.; Wilson, E.; Nielsen, B.; Kauwe, J.; Hedges, D.W. Seroprevalence and Serointensity of Latent Toxoplasma gondii in a Sample of Elderly Adults With and Without Alzheimer Disease. Alzheimer Dis. Assoc. Disord. 2016, 30, 123-126. [CrossRef]

79. Carter, C.J. Toxoplasmosis and Polygenic Disease Susceptibility Genes: Extensive Toxoplasma gondii Host/Pathogen Interactome Enrichment in Nine Psychiatric or Neurological Disorders. J. Pathog. 2013, 2013, 965046. [CrossRef]

80. Mahmoudi, S.; Mamishi, S.; Suo, X.; Keshavarz, H. Early detection of Toxoplasma gondii infection by using a interferon gamma release assay: A review. Exp. Parasitol. 2017, 172, 39-43. [CrossRef]

81. Torres, L.; Robinson, S.A.; Kim, D.G.; Yan, A.; Cleland, T.A.; Bynoe, M.S. Toxoplasma gondii alters NMDAR signaling and induces signs of Alzheimer's disease in wild-type, C57BL/6 mice. J. Neuroinflamm. 2018, 15, 57. [CrossRef]

82. Mohle, L.; Israel, N.; Paarmann, K.; Krohn, M.; Pietkiewicz, S.; Müller, A.; Lavrik, I.N.; Buguliskis, J.S.; Schott, B.H.; Schlüter, D.; et al. Chronic Toxoplasma gondii infection enhances beta-amyloid phagocytosis and clearance by recruited monocytes. Acta Neuropathol. Commun. 2016, 4, 25. [CrossRef]

83. Jung, B.K.; Pyo, K.H.; Shin, K.Y.; Hwang, Y.S.; Lim, H.; Lee, S.J.; Moon, J.H.; Lee, S.H.; Suh, Y.H.; Chai, J.Y.; et al. Toxoplasma gondii infection in the brain inhibits neuronal degeneration and learning and memory impairments in a murine model of Alzheimer's disease. PLoS ONE 2012, 7, e33312. [CrossRef]

84. Shin, J.H.; Hwang, Y.S.; Jung, B.K.; Seo, S.H.; Ham, D.W.; Shin, E.H. Reduction of Amyloid Burden by Proliferated Homeostatic Microglia in Toxoplasma gondii-Infected Alzheimer's Disease Model Mice. Int. J. Mol. Sci. 2021, 22, 2764. [CrossRef]

85. Ortiz-Guerrero, G.; Gonzalez-Reyes, R.E.; de-la-Torre, A.; Medina-Rincón, G.; Nava-Mesa, M.O. Pathophysiological Mechanisms of Cognitive Impairment and Neurodegeneration by Toxoplasma gondii Infection. Brain Sci. 2020, 10, 369. [CrossRef]

86. Tong, W.H.; Pavey, C.; O’Handley, R.; Vyas, A. Behavioral biology of Toxoplasma gondii infection. Parasit. Vectors 2021, 14, 77. [CrossRef]

87. Milne, G.; Webster, J.P.; Walker, M. Toxoplasma gondii: An. Underestimated Threat? Trends Parasitol. 2020, 36, 959-969. [CrossRef] 
88. Boillat, M.; Hammoudi, P.M.; Dogga, S.K.; Pagès, S.; Goubran, M.; Rodriguez, I.; Soldati-Favre, D. Neuroinflammation-Associated Aspecific Manipulation of Mouse Predator Fear by Toxoplasma gondii. Cell Rep. 2020, 30, 320-334. [CrossRef] [PubMed]

89. Severance, E.G.; Xiao, J.; Jones-Brando, L.; Sabunciyan, S.; Li, Y.; Pletnikov, M.; Prandovszky, E.; Yolken, R. Toxoplasma gondii-A Gastrointestinal Pathogen Associated with Human Brain Diseases. Int. Rev. Neurobiol. 2016, 131, 143-163. [PubMed]

90. Sutterland, A.L.; Fond, G.; Kuin, A.; Koeter, M.W.J.; Lutter, R.; Gool, T.V.; Yolken, R.; Szoke, A.; Leboyer, M.; de Haan, L. Toxoplasma gondii in schizophrenia, bipolar disorder, and addiction: Systematic review and meta-analysis. Acta. Psychiatr. Scand. 2015, 132, 161-179. [CrossRef] [PubMed]

91. Gatkowska, J.; Wieczorek, M.; Dziadek, B.; Dzitko, K.; Dlugonska, H. Sex-dependent neurotransmitter level changes in brains of Toxoplasma gondii infected mice. Exp. Parasitol. 2013, 133, 1-7. [CrossRef]

92. Prandovszky, E.; Gaskell, E.; Martin, H.; Dubey, J.P.; Webster, J.P.; McConkey, G.A. The Neurotropic Parasite Toxoplasma Gondii Increases Dopamine Metabolism. PLoS ONE 2011, 6, e23866. [CrossRef] [PubMed]

93. Skallova, A.; Kodym, P.; Frynta, D.; Flegr, J. The role of dopamine in Toxoplasma-induced behavioural alterations in mice: An ethological and ethopharmacological study. Parasitology 2006, 133, 525-535. [CrossRef]

94. Wang, Z.T.; Harmon, S.; O'Malley, K.L.; Sibley, D.L. Reassessment of the role of aromatic amino acid hydroxylases and the effect of infection by Toxoplasma gondii on host dopamine. Infect Immun. 2015, 83, 1039-1047. [CrossRef]

95. Patten, S.B.; Kennedy, S.H.; Lam, R.W.; O’Donovan, C.; Filteau, M.J.; Parikh, S.V.; Ravindran, A.V. Canadian Network for Mood and Anxiety Treatments (CANMAT) clinical guidelines for the management of major depressive disorder in adults. J. Affect. Disord. 2009, 117, S5-S14. [CrossRef]

96. Daubener, W.; Spors, B.; Hucke, C.; Adam, R.; Stins, M.; Kim, K.S.; Schroten, H. Restriction of Toxoplasma gondii growth in human brain microvascular endothelial cells by activation of indoleamine 2,3-dioxygenase. Infect. Immun. 2001, 69, 6527-6531. [CrossRef] [PubMed]

97. Murakami, Y.; Hoshi, M.; Hara, A.; Takemura, M.; Arioka, Y.; Yamamoto, Y.; Matsunami, H.; Funato, T.; Seishima, M.; Saito, K. Inhibition of increased indoleamine 2,3-dioxygenase activity attenuates Toxoplasma gondii replication in the lung during acute infection. Cytokine 2012, 59, 245-251. [CrossRef] [PubMed]

98. Carruthers, V.B.; Suzuki, Y. Effects of Toxoplasma gondii Infection on the Brain. Schizophr. Bull. 2007, 33, 745-751. [CrossRef]

99. Dalimi, A.; Abdoli, A. Latent toxoplasmosis and human. Iran. J. Parasitol. 2012, 7, 1-17. [PubMed]

100. Mahmoud, M.E.; Fereig, R.; Nishikawa, Y. Involvement of Host Defense Mechanisms against Toxoplasma gondii Infection in Anhedonic and Despair-Like Behaviors in Mice. Infect. Immun. 2017, 85, e00007-e00017. [CrossRef]

101. Webster, J.P.; McConkey, G.A. Toxoplasma gondii-altered host behaviour: Clues as to mechanism of action. Folia. Parasitol. (Praha) 2010, 57, 95-104. [CrossRef]

102. Bay-Richter, C.; Buttenschøn, H.N.; Mors, O.; Eskelund, A.; Budac, D.; Kærlev, L.; Wegener, G. Latent toxoplasmosis and psychiatric symptom: A role of tryptophan metabolism? J. Psychiatr. Res. 2019, 110, 45-50. [CrossRef] [PubMed]

103. Notarangelo, F.M.; Wilson, E.H.; Horning, K.J.; Thomas, M.A.R.; Harris, T.H.; Fang, Q.; Hunter, C.A.; Schwarcz, R. Evaluation of kynurenine pathway metabolism in Toxoplasma gondii-infected mice: Implications for schizophrenia. Schizophr Res. 2014, 152, 261-267. [CrossRef]

104. Erhardt, S.; Schwieler, L.; Imbeault, S.; Engberg, G. The kynurenine pathway in schizophrenia and bipolar disorder. Neuropharmacology 2017, 112, 297-306. [CrossRef]

105. Zhang, Z.; Li, Y.; Li, H.; Song, X.; Ma, Z.; Lu, H.; Liu, S.; Zhao, Y.; Tan, M.; Wang, S.; et al. Identification of Toxoplasma Gondii Tyrosine Hydroxylase (TH) Activity and Molecular Immunoprotection against Toxoplasmosis. Vaccines 2020, 8, 158. [CrossRef] [PubMed]

106. Flegr, J.; Horacek, J. Negative Effects of Latent Toxoplasmosis on Mental Health. Front. Psychiatry 2019, 10, 1012. [CrossRef] [PubMed]

107. Bak, J.; Shim, S.H.; Kwon, Y.J.; Lee, H.Y.; Kim, J.S.; Yoon, H.; Lee, Y.J. The Association between Suicide Attempts and Toxoplasma gondii Infection. Clin. Psychopharmacol. Neurosci. 2018, 16, 95-102. [CrossRef]

108. Ling, V.J.; Lester, D.; Mortensen, P.B.; Langenberg, P.W.; Postolache, T.T. Toxoplasma gondii seropositivity and suicide rates in women. J. Nerv. Ment. Dis. 2011, 199, 440-444.

109. Postolache, T.T.; Wadhawan, A.; Rujescu, D.; Hoisington, A.J.; Dagdag, A.; Baca-Garcia, E.; Lowry, C.A.; Okusaga, O.O.; Brenner, L.A. Toxoplasma gondii, Suicidal Behavior, and Intermediate Phenotypes for Suicidal Behavior. Front. Psychiatry 2021, $12,665682$. [CrossRef]

110. Kar, N.; Misra, B. Toxoplasma seropositivity and depression: A case report. BMC Psychiatry 2004, 4, 1. [CrossRef]

111. Horacek, J.; Flegr, J.; Tintera, J.; Verebova, K.; Spaniel, F.; Novak, T.; Brunovsky, M.; Bubenikova-Valesova, V.; Holub, D.; Palenicek, T.; et al. Latent toxoplasmosis reduces gray matter density in schizophrenia but not in controls: Voxel-based-morphometry (VBM) study. World J. Biol. Psychiatry 2012, 13, 501-509. [CrossRef]

112. Torrey, E.F.; Bartko, J.J.; Lun, Z.R.; Yolken, R.H. Antibodies to Toxoplasma gondii in patients with schizophrenia: A meta-analysis. Schizophr Bull. 2007, 33, 729-736. [CrossRef]

113. Torrey, E.F.; Bartko, J.J.; Yolken, R.H. Toxoplasma gondii and other risk factors for schizophrenia: An update. Schizophr Bull. 2012, 38, 642-647. [CrossRef]

114. Chen, X.; Chen, B.; Hou, X.; Zheng, C.; Yang, X.; Ke, J.; Hu, X.; Tan, F. Association between Toxoplasma gondii infection and psychiatric disorders in Zhejiang, Southeastern China. Acta Trop. 2019, 192, 82-86. [CrossRef] 
115. Burgdorf, K.S.; Trabjerg, B.B.; Pedersen, M.G.; Nissen, J.; Banasik, K.; Pedersen, O.B.; Sørensen, E.; Nielsen, K.R.; Larsen, M.H.; Erikstrup, C.; et al. Large-scale study of Toxoplasma and Cytomegalovirus shows an association between infection and serious psychiatric disorders. Brain Behav. Immun. 2019, 79, 152-158. [CrossRef] [PubMed]

116. Avramopoulos, D.; Pearce, B.D.; McGrath, J.; Wolyniec, P.; Wang, R.; Eckart, N.; Hatzimanolis, A.; Goes, F.S.; Nestadt, G.; Mulle, J.; et al. Infection and inflammation in schizophrenia and bipolar disorder: A genome wide study for interactions with genetic variation. PLoS ONE 2015, 10, e0116696. [CrossRef] [PubMed]

117. Majláth, Z.; Török, N.; Toldi, J.; Vécsei, L. Memantine and Kynurenic Acid: Current Neuropharmacological Aspects. Curr. Neuropharmacol. 2016, 14, 200-209. [CrossRef] [PubMed]

118. Pocivavsek, A.; Wu, H.Q.; Potter, M.C.; Elmer, G.I.; Pellicciari, R.; Schwarcz, R. Fluctuations in Endogenous Kynurenic Acid Control Hippocampal Glutamate and Memory. Neuropsychopharmacology 2011, 36, 2357-2367. [CrossRef] [PubMed]

119. Kano, S.I.; Hodgkinson, C.A.; Jones-Brando, L.; Eastwood, S.; Ishizuka, K.; Niwa, M.; Choi, E.Y.; Chang, D.J.; Chen, Y.; Velivela, S.D.; et al. Host-parasite interaction associated with major mental illness. Mol. Psychiatry 2020, 25, 194-205. [CrossRef]

120. Bhadra, R.; Gigley, J.P.; Weiss, L.M.; Khan, I.A. Control of Toxoplasma reactivation by rescue of dysfunctional CD8+ T-cell response via PD-1-PDL-1 blockade. Proc. Natl. Acad. Sci. USA 2011, 108, 9196-9201. [CrossRef]

121. Steiner, J.; Jacobs, R.; Panteli, B.; Brauner, M.; Schiltz, K.; Bahn, S.; Herberth, M.; Westphal, S.; Gos, T.; Walter, M.; et al. Acute schizophrenia is accompanied by reduced T cell and increased B cell immunity. Eur. Arch. Psychiatry Clin. Neurosci. 2010, 260, 509-518. [CrossRef]

122. Torrey, E.F.; Yolken, R.H. Toxoplasma gondii and Schizophrenia. Emerg. Infect. Dis. J. 2003, 9, 1375. [CrossRef]

123. Hamdani, N.; Daban-Huard, C.; Lajnef, M.; Richard, J.R.; Delavest, M.; Godin, O.; Le Guen, E.; Vederine, F.E.; Lépine, J.P.; Jamain, S.; et al. Relationship between Toxoplasma gondii infection and bipolar disorder in a French sample. J. Affect. Disord. 2013, 148, 444-448. [CrossRef] [PubMed]

124. Hussein, E.A.M.; Khalifa, H.; Ramadan, G.K.; Hassaan, S.H.; Shaaban, I.; Farrag, H.M.M. Seroprevalence of Toxoplasma gondii among patients with schizophrenia and bipolar disorder in Upper Egypt: A comparative study with a control group. Ann. Parasitol. 2020, 66, 183-192. [PubMed]

125. Pearce, B.D.; Kruszon-Moran, D.; Jones, J.L. The Relationship Between Toxoplasma gondii Infection and Mood Disorders in the Third National Health and Nutrition Survey. Biol. Psychiatry 2012, 72, 290-295. [CrossRef]

126. Tedla, Y.; Shibre, T.; Ali, O.; Tadele, G.; Woldeamanuel, Y.; Asrat, D.; Aseffa, A.; Mihret, W.; Abebe, M.; Alem, A.; et al. Serum antibodies to Toxoplasma gondii and Herpesvidae family viruses in individuals with schizophrenia and bipolar disorder: A case-control study. Ethiop. Med. J. 2011, 49, 211-220. [PubMed]

127. de Barros, J.; Barbosa, I.G.; Salem, H.; Rocha, N.P.; Kummer, A.; Okusaga, O.O.; Soares, J.C.; Teixeira, A.L. Is there any association between Toxoplasma gondii infection and bipolar disorder? A systematic review and meta-analysis. J. Affect. Disord. 2017, 209, 59-65. [CrossRef]

128. Del Grande, C.; Galli, L.; Schiavi, E.; Dell'Osso, L.; Bruschi, F. Is Toxoplasma gondii a Trigger of Bipolar Disorder? Pathogens 2017, 6, 3. [CrossRef]

129. Nayeri Chegeni, T.; Sarvi, S.; Amouei, A.; Moosazadeh, M.; Hosseininejad, Z.; Aghayan, S.A.; Daryani, A. Relationship between toxoplasmosis and obsessive compulsive disorder: A systematic review and meta-analysis. PLoS Negl. Trop. Dis. 2019, 13, e0007306. [CrossRef]

130. Akaltun, İ.; Kara, S.S.; Kara, T. The relationship between Toxoplasma gondii IgG antibodies and generalized anxiety disorder and obsessive-compulsive disorder in children and adolescents: A new approach. Nord. J. Psychiatry 2018, 72, 57-62. [CrossRef]

131. Brynska, A.; Tomaszewicz-Libudzic, E.; Wolanczyk, T. Obsessive-compulsive disorder and acquired toxoplasmosis in two children. Eur. Child Adolesc. Psychiatry 2001, 10, 200-204. [CrossRef]

132. Hodge, J.M.; Coghill, A.E.; Kim, Y.; Bender, N.; Smith-Warner, S.A.; Gapstur, S.; Teras, L.R.; Grimsrud, T.K.; Waterboer, T.; Egan, K.M. Toxoplasma gondii infection and the risk of adult glioma in two prospective studies. Int. J. Cancer 2021. [CrossRef] [PubMed]

133. Ryan, P.; Hurley, S.F.; Johnson, A.M.; Salzberg, M.; Lee, M.W.; North, J.B.; McNeil, J.J.; McMichael, A.J. Tumours of the Brain and Presence of Antibodies to Toxoplasma gondii. Int. J. Epidemiol. 1993, 22, 412-419. [CrossRef] [PubMed]

134. Thomas, F.; Lafferty, K.D.; Brodeur, J.; Elguero, E.; Gauthier-Clerc, M.; Missé, D. Incidence of adult brain cancers is higher in countries where the protozoan parasite Toxoplasma gondii is common. Biol. Lett. 2012, 8, 101-103. [CrossRef] [PubMed]

135. Zeiner, G.M.; Norman, K.L.; Thomson, J.M.; Hammond, S.M.; Boothroyd, J.C. Toxoplasma gondii infection specifically increases the levels of key host microRNAs. PLoS ONE 2010, 5, e8742. [CrossRef]

136. Thirugnanam, S.; Rout, N.; Gnanasekar, M. Possible role of Toxoplasma gondii in brain cancer through modulation of host microRNAs. Infect. Agent Cancer 2013, 8, 8. [CrossRef] [PubMed]

137. Colinot, D.L.; Garbuz, T.; Bosland, M.C.; Wang, L.; Rice, S.E.; Sullivan, W.J.; Arrizabalaga, G.; Jerde, T.J. The common parasite Toxoplasma gondii induces prostatic inflammation and microglandular hyperplasia in a mouse model. Prostate 2017, 77, 1066-1075. [CrossRef] [PubMed]

138. Cong, W.; Liu, G.H.; Meng, Q.F.; Dong, W.; Qin, S.Y.; Zhang, F.K.; Zhang, X.Y.; Wang, X.Y.; Qian, A.D.; Zhu, X.Q. Toxoplasma gondii infection in cancer patients: Prevalence, risk factors, genotypes and association with clinical diagnosis. Cancer Lett. 2015, 359, 307-313. [CrossRef]

139. Jung, B.-K.; Song, H.; Kim, M.J.; Cho, J.; Shin, E.H.; Chai, J.Y. High Toxoplasma gondii Seropositivity among Brain Tumor Patients in Korea. Korean J. Parasitol. 2016, 54, 201-204. [CrossRef] 
140. de Faria Junior, G.M.; Murata, F.H.A.; Lorenzi, H.A.; Castro, B.B.P.; Assoni, L.C.P.; Ayo, C.M.; Brandão, C.C.; de Mattos, L.C. The Role of microRNAs in the Infection by T. gondii in Humans. Front. Cell Infect. Microbiol. 2021, 11, 670548. [CrossRef]

141. Zeiner, G.M.; Boothroyd, J.C. Use of two novel approaches to discriminate between closely related host microRNAs that are manipulated by Toxoplasma gondii during infection. RNA 2010, 16, 1268-1274. [CrossRef]

142. Carmen, J.C.; Sinai, A.P. Suicide prevention: Disruption of apoptotic pathways by protozoan parasites. Mol. Microbiol. 2007, 64, 904-916. [CrossRef] [PubMed]

143. Lüder, C.G.; Gross, U. Apoptosis and its modulation during infection with Toxoplasma gondii: Molecular mechanisms and role in pathogenesis. Curr. Top. Microbiol. Immunol. 2005, 289, 219-237. [PubMed]

144. Qian, Y.; Song, J.; Ouyang, Y.; Han, Q.; Chen, W.; Zhao, X.; Xie, Y.; Chen, Y.; Yuan, W.; Fan, C. Advances in Roles of miR-132 in the Nervous System. Front. Pharmacol. 2017, 8, 770. [CrossRef]

145. Xiao, J.; Li, Y.; Prandovszky, E.; Karuppagounder, S.S.; Talbot, C.C.; Dawson, V.L.; Dawson, T.M.; Yolken, R.H. MicroRNA-132 dysregulation in Toxoplasma gondii infection has implications for dopamine signaling pathway. Neuroscience 2014, 268, 128-138. [CrossRef]

146. Pang, J.C.-s.; Kwok, W.K.; Chen, Z.; Ng, H.K. Oncogenic role of microRNAs in brain tumors. Acta Neuropathol. 2009, $117,599-611$. [CrossRef]

147. Turner, J.D.; Williamson, R.; Almefty, K.K.; Nakaji, P.; Porter, R.; Tse, V.M.; Kalani, Y.S. The many roles of microRNAs in brain tumor biology. Neurosurg. Focus 2010, 28, e3.

148. Wang, D.; Qiu, C.; Zhang, H.; Wang, J.; Cui, Q.; Yin, Y. Human MicroRNA Oncogenes and Tumor Suppressors Show Significantly Different Biological Patterns: From Functions to Targets. PLoS ONE 2010, 5, e13067. [CrossRef]

149. Vittecoq, M.; Elguero, E.; Lafferty, K.D.; Roche, B.; Brodeur, J.; Gauthier-Clerc, M.; Missé, D.; Thomas, F. Brain cancer mortality rates increase with Toxoplasma gondii seroprevalence in France. Infect. Genet. Evol. 2012, 12, 496-498. [CrossRef]

150. Ernst, A.; Campos, B.; Meier, J.; Devens, F.; Liesenberg, F.; Wolter, M.; Reifenberger, G.; Herold-Mende, C.; Lichter, P.; Radlwimmer, B. De-repression of CTGF via the miR-17-92 cluster upon differentiation of human glioblastoma spheroid cultures. Oncogene 2010, 29, 3411-3422. [CrossRef] [PubMed]

151. Uziel, T.; Karginov, F.V.; Xie, S.; Parker, J.S.; Wang, Y.D.; Gajjar, A.; He, L.; Ellison, D.; Gilbertson, R.J.; Hannon, G.; et al. The miR-17 92 cluster collaborates with the Sonic Hedgehog pathway in medulloblastoma. Proc. Natl. Acad. Sci. USA 2009, 106, 2812. [CrossRef] [PubMed]

152. Laliberté, J.; Carruthers, V.B. Host cell manipulation by the human pathogen Toxoplasma gondii. Cell. Mol. Life Sci. 2008, 65, 1900-1915. [CrossRef]

153. Braun, L.; Cannella, D.; Ortet, P.; Barakat, M.; Sautel, C.F.; Kieffer, S.; Garin, J.; Bastien, O.; Voinnet, O.; Hakimi, M.A. A complex small RNA repertoire is generated by a plant/fungal-like machinery and effected by a metazoan-like Argonaute in the single-cell human parasite Toxoplasma gondii. PLoS Pathog. 2010, 6, e1000920. [CrossRef]

154. Dunay, I.R.; Gajurel, K.; Dhakal, R.; Liesenfeld, O.; Montoya, J.G. Treatment of Toxoplasmosis: Historical Perspective, Animal Models, and Current Clinical Practice. Clin. Microbiol. Rev. 2018, 31, e00057-17. [CrossRef]

155. Konstantinovic, N.; Guegan, H.; Stäjner, T.; Belaz, S.; Robert-Gangneux, F. Treatment of toxoplasmosis: Current options and future perspectives. Food Waterborne Parasitol. 2019, 15, e00036. [CrossRef] [PubMed]

156. Blume, M.; Seeber, F. Metabolic interactions between Toxoplasma gondii and its host. F1000Research 2018. [CrossRef] [PubMed]

157. Lapinskas, P.J.; Ben-Harari, R.R. Perspective on current and emerging drugs in the treatment of acute and chronic toxoplasmosis. Postgrad Med. 2019, 131, 589-596. [CrossRef]

158. Remington, J.S.; Thulliez, P.; Montoya, J.G. Recent Developments for Diagnosis of Toxoplasmosis. J. Clin. Microbiol. 2004, $42,941$. [CrossRef]

159. Katlama, C.; Mouthon, B.; Gourdon, D.; Lapierre, D.; Rousseau, F. Atovaquone as long-term suppressive therapy for toxoplasmic encephalitis in patients with AIDS and multiple drug intolerance. Aids 1996, 10, 1107-1112.

160. Ben-Harari, R.R.; Goodwin, E.; Casoy, J. Adverse Event Profile of Pyrimethamine-Based Therapy in Toxoplasmosis: A Systematic Review. Drugs R D 2017, 17, 523-544. [CrossRef] [PubMed]

161. Katlama, C.; De Wit, S.; O’Doherty, E.; Van Glabeke, M.; Clumeck, N. Pyrimethamine-clindamycin vs. pyrimethamine-sulfadiazine as acute and long-term therapy for toxoplasmic encephalitis in patients with AIDS. Clin. Infect. 1996, 22, 268-275. [CrossRef] [PubMed]

162. Montazeri, M.; Mehrzadi, S.; Sharif, M.; Sarvi, S.; Tanzifi, A.; Aghayan, S.A.; Daryani, A. Drug Resistance in Toxoplasma gondii. Front. Microbiol. 2018, 9, 2587. [CrossRef] [PubMed]

163. Robert-Gangneux, F.; Binisti, P.; Antonetti, D.; Brezin, A.; Yera, H.; Dupouy-Camet, J. Usefulness of immunoblotting and Goldmann-Witmer coefficient for biological diagnosis of toxoplasmic retinochoroiditis. Eur. J. Clin. Microbiol. Infect. Dis. 2004, 23, 34-38. [CrossRef] [PubMed]

164. Rodríguez-Díaz, J.C.; Martínez-Grueiro, M.M.; Martínez-Fernández, A.R. Comparative activity of several antibiotics against Toxoplasma gondii in a mouse model. Enferm. Infect. Microbiol. Clin. 1993, 11, 543-546.

165. Schmidt, D.R.; Hogh, B.; Andersen, O.; Hansen, S.H.; Dalhoff, K.; Petersen, E. Treatment of infants with congenital toxoplasmosis: Tolerability and plasma concentrations of sulfadiazine and pyrimethamine. Eur. J. Pediatrics 2006, 165, 19-25. [CrossRef] [PubMed] 
166. Alday, P.H.; Doggett, J.S. Drugs in development for toxoplasmosis: Advances, challenges, and current status. Drug Des. Dev. Ther. 2017, 11, 273-293. [CrossRef] [PubMed]

167. Montazeri, M.; Sharif, M.; Sarvi, S.; Mehrzadi, S.; Ahmadpour, E.; Daryani, A. A Systematic Review of In vitro and In vivo Activities of Anti-Toxoplasma Drugs and Compounds (2006-2016). Front. Microbiol. 2017, 8, 25. [CrossRef] [PubMed]

168. Değerli, K.; Kilimcioğlu, A.A.; Kurt, O.; Tamay, A.T.; Ozbilgin, A. Efficacy of azithromycin in a murine toxoplasmosis model, employing a Toxoplasma gondii strain from Turkey. Acta Trop. 2003, 88, 45-50. [CrossRef]

169. Benmerzouga, I.; Checkley, L.A.; Ferdig, M.T.; Arrizabalaga, G.; Wek, R.C.; Sullivan, W.J., Jr. Guanabenz repurposed as an antiparasitic with activity against acute and latent toxoplasmosis. Antimicrob. Agents Chemother. 2015, 59, 6939-6945. [CrossRef]

170. Hamie, M.; Najm, R.; Deleuze-Masquefa, C.; Bonnet, P.A.; Dubremetz, J.F.; El Sabban, M.; El Hajj, H. Imiquimod Targets Toxoplasmosis Through Modulating Host Toll-Like Receptor-MyD88 Signaling. Front. Immunol. 2021, 12, 629917. [CrossRef] [PubMed]

171. Mevelec, M.N.; Lakhrif, Z.; Dimier-Poisson, I. Key Limitations and New Insights Into the Toxoplasma gondii Parasite Stage Switching for Future Vaccine Development in Human, Livestock, and Cats. Front. Cell Infect. Microbiol. 2020, $10,607198$. [CrossRef]

172. Buxton, D.; Innes, E.A. A commercial vaccine for ovine toxoplasmosis. Parasitol 1995, 110, S11-S16. [CrossRef]

173. Innes, E.A.; Bartley, P.M.; Buxton, D.; Katzer, F. Ovine Toxoplasmosis. Parasitology 2009, 136, 1887-1894. [CrossRef]

174. Dodangeh, S.; Daryani, A.; Sharif, M.; Aghayan, S.A.; Pagheh, A.S.; Sarvi, S.; Rezaei, F. A systematic review on efficiency of microneme proteins to induce protective immunity against Toxoplasma gondii. Eur. J. Clin. Microbiol. Infect. Dis. 2019, 38, 617-629. [CrossRef]

175. Faridnia, R.; Daryani, A.; Sarvi, S.; Sharif, M.; Kalani, H. Vaccination against Toxoplasma gondii using rhoptry antigens: A systematic review. Comp. Immunol. Microbiol. Infect. Dis. 2018, 59, 32-40. [CrossRef] [PubMed]

176. Zhang, Y.; Träskman-Bendz, L.; Janelidze, S.; Langenberg, P.; Saleh, A.; Constantine, N.; Okusaga, O.; Bay-Richter, C.; Brundin, L.; Postolache, T.T. Toxoplasma gondii immunoglobulin G antibodies and nonfatal suicidal self-directed violence. J. Clin. Psychiatry 2012, 73, 1069-1076. [CrossRef]

177. Siachoque, H.; Guzman, F.; Burgos, J.; Patarroyo, M.E.; Gomez Marin, J.E. Toxoplasma gondii: Immunogenicity and protection by P30 peptides in a murine model. Exp. Parasitol. 2006, 114, 62-65. [CrossRef] [PubMed]

178. Yang, Y.W.; Wu, C.A.; Morrow, W.J. Cell death induced by vaccine adjuvants containing surfactants. Vaccine 2004, 22, 1524-1536. [CrossRef]

179. Bonenfant, C.; Dimier-Poisson, I.; Velge-Roussel, F.; Buzoni-Gatel, D.; Del Giudice, G.; Rappuoli, R.; Bout, D. Intranasal immunization with SAG1 and nontoxic mutant heat-labile enterotoxins protects mice against Toxoplasma gondii. Infect. Immun. 2001, 69, 1605-1612. [CrossRef]

180. Letscher-Bru, V.; Villard, O.; Risse, B.; Zauke, M.; Klein, J.P.; Kien, T.T. Protective effect of vaccination with a combination of recombinant surface antigen 1 and interleukin-12 against toxoplasmosis in mice. Infect. Immun. 1998, 66, 4503-4506. [CrossRef] [PubMed]

181. Martin, V.; Supanitsky, A.; Echeverria, P.C.; Litwin, S.; Tanos, T.; De Roodt, A.R.; Guarnera, E.A.; Angel, S.O. Recombinant GRA4 or ROP2 Protein Combined with Alum or the GRA4 Gene Provides Partial Protection in Chronic Murine Models of Toxoplasmosis. Clin. Diagn. Lab. Immunol. 2004, 11, 704-710. [CrossRef]

182. Cérède, O.; Dubremetz, J.F.; Soête, M.; Deslée, D.; Vial, H.; Bout, D.; Lebrun, M. Synergistic role of micronemal proteins in Toxoplasma gondii virulence. J. Exp. Med. 2005, 201, 453-463. [CrossRef] [PubMed]

183. Jongert, E.; Verhelst, D.; Abady, M.; Petersen, E.; Gargano, N. Protective Th1 immune responses against chronic toxoplasmosis induced by a protein-protein vaccine combination but not by its DNA-protein counterpart. Vaccine 2008, 26, 5289-5295. [CrossRef] [PubMed]

184. Rezaei, F.; Sarvi, S.; Sharif, M.; Hejazi, S.H.; Pagheh, A.S.; Aghayan, S.A.; Daryani, A. A systematic review of Toxoplasma gondii antigens to find the best vaccine candidates for immunization. Microb. Pathog. 2019, 126, 172-184. [CrossRef] [PubMed]

185. El Bissati, K.; Chentoufi, A.A.; Krishack, P.A.; Zhou, Y.; Woods, S.; Dubey, J.P.; Vang, L.; Lykins, J.; Broderick, K.E.; Ernest, M.; et al. Adjuvanted multi-epitope vaccines protect HLA-A*11:01 transgenic mice against Toxoplasma gondii. JCI Insight 2020, 1, 15. [CrossRef] [PubMed]

186. Ahmadpour, E.; Sarvi, S.; Soteh, M.B.H.; Sharif, M.; Rahimi, M.T.; Valadan, R.; Tehrani, M.; Khalilian, A.; Montazeri, M.; Fasihi-Ramandi, M.; et al. Enhancing immune responses to a DNA vaccine encoding Toxoplasma gondii GRA14 by calcium phosphate nanoparticles as an adjuvant. Immunol. Lett. 2017, 185, 40-47. [CrossRef]

187. Allahyari, M.; Mohabati, R.; Amiri, S.; Rastaghi, A.R.E.; Babaie, J.; Mahdavi, M.; Vatanara, A.; Golkar, M. Synergistic effect of rSAG1 and rGRA2 antigens formulated in PLGA microspheres in eliciting immune protection against Toxoplasama gondii. Exp. Parasitol. 2016, 170, 236-246. [CrossRef]

188. Lee, D.H.; Kim, A.R.; Lee, S.H.; Quan, F.S. Cross-protection induced by Toxoplasma gondii virus-like particle vaccine upon intraperitoneal route challenge. Acta Trop. 2016, 164, 77-83. [CrossRef] 